\title{
Mathematical Modeling of Landfill Gas (MSW)-Production of Gas with Methane Gas Content from Landfills (MSW)
}

\author{
Danila Vieru \\ Romanian Expert on Environmental Issues, Bucharest, Romania, Member of AGIR (Romanian Engineers Association), Bucharest, \\ Romania \\ Email: danila.vieru@gmail.com
}

How to cite this paper: Vieru, D. (2020). Mathematical Modeling of Landfill Gas (MSW)-Production of Gas with Methane Gas Content from Landfills (MSW). Journal of Geoscience and Environment Protection, 8, 36-62.

https://doi.org/10.4236/gep.2020.812003

Received: September 11, 2020

Accepted: December 6, 2020

Published: December 9, 2020

Copyright $\odot 2020$ by author(s) and Scientific Research Publishing Inc. This work is licensed under the Creative Commons Attribution International License (CC BY 4.0).

http://creativecommons.org/licenses/by/4.0/

\begin{abstract}
The municipal solid waste (msw) is a source of landfill gas (msw) - with methane gas content. Preoccupations for landfill gas (msw) management date back since 1976 when, at a landfill (msw) in California (USA), it turned out practically that the landfill gas ( $\mathrm{msw}$ ) with methane gas content contains a gas with high caloric value that can be collected and used for economic purposes. The landfill gas (msw) contains methane gas (30\%-60\% volume), carbon dioxide ( $45 \%$ - 50\% volume), hydrogen sulfide and other gases. Methane gas, carbon dioxide, nitrous oxide and other gases are listed in Kyoto Protocol as high greenhouse gases. Their ecological-rational management is both a national and global preoccupation. In terms of greenhouse gases, especially methane gas, the landfill (msw) is held responsible for 3.5\% - 5\% of the total global greenhouse gases. Practically, the quantitative estimation of the methane gas in a municipal solid waste landfill can be done by measuring the landfill gas (msw) flow in an extraction-collection well. In Romania, a quantitative estimation relationship of methane gas from deposits (msw) was made, approaching the problem in a different way. This paper presents the calculation formula, the working algorithm, the municipal waste landfill equation and the NOMOGRAMA of a municipal solid waste landfill (msw). The NOMOGRAMA allows us to define the values for parameter -m- (number of months needed for an amount of municipal solid waste (msw) to degrade, starting with the year from which the landfill gas (msw) emission with methane gas content is calculated). Taking into account the environmental conditions for each location of municipal solid waste landfill, the calculation uses various indexes and approximations, while the fundamental parameter remains - $m$ - defined by the NOMOGRAMA of the municipal solid waste landfill (msw). A municipal solid waste landfill ( $\mathrm{msw}$ ) is a conglomerate of waste
\end{abstract}


with various biodegradation periods between $2-3$ years and 5 - 10 - 30 years. Degradation of waste (msw) in to dissolved organic carbon will take place in a number of months defined -m- starting with the year from which the methane gas emission with the NOMOGRAMA of the municipal solid waste landfill ( $\mathrm{msw}$ ) is calculated. The - $\mathrm{m}$ - values for the year of the quantitative emission of methane gas can be also done analytically, which requires good experience in the ecologic-rational management of the municipal solid waste (msw).

\section{Keywords}

Municipal Solid Waste (MSW), NOMOGRAMA, Calculation Formula, Parameter -m-, Quantitative Estimation of Methane Gas

\section{Introduction}

In terms of environmental conditions, Romania is considered to have an European wet continental-temperate climate with slight influence from the mountains, so that [Romania's Climate Wikipedia, 2008] summers are dry (20 May-20 September), with temperatures between $30^{\circ} \mathrm{C}-40^{\circ} \mathrm{C}$, precipitations between $637 \mathrm{~mm}-400 \mathrm{~mm} /$ year. In the mountains, precipitations are between $1000-1400 \mathrm{~mm} /$ year. In the spring time, 20 February-20 May, and in autumn, 20 September-20 November, temperatures are between $10^{\circ} \mathrm{C}-30^{\circ} \mathrm{C}$, and moderate precipitations. During winter, 20 November-20 February, temperatures are between $-5^{\circ} \mathrm{C}$ and $-25^{\circ} \mathrm{C}$. Snow alternates with freezing-refreezing periods. Romania, as an European country has a climate distribution as shown in Figure 1.

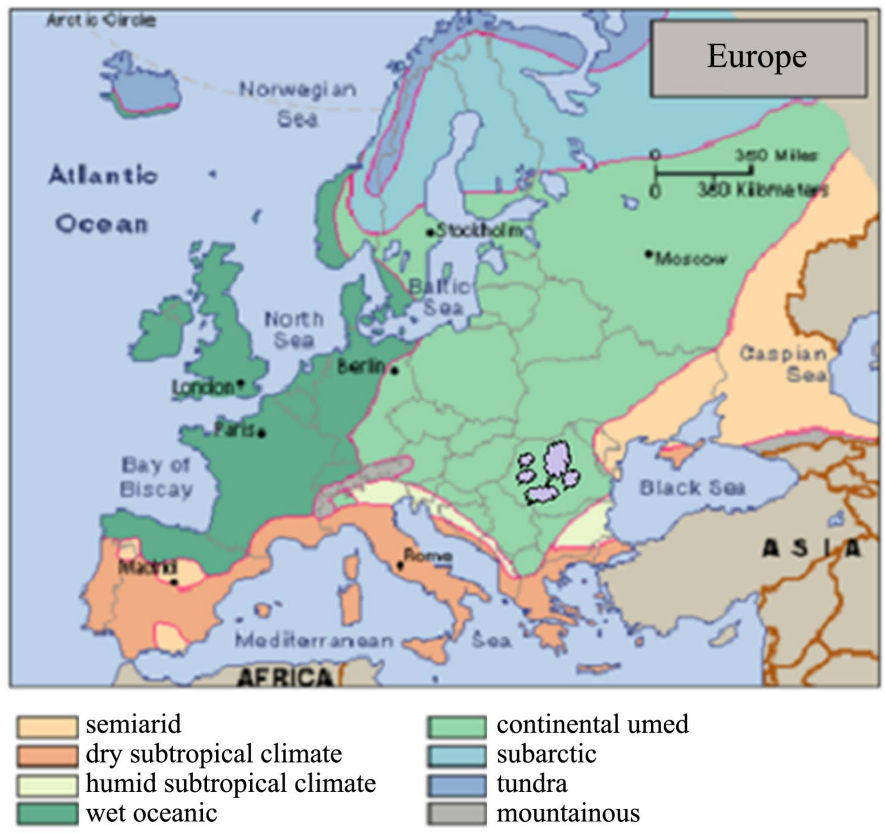

Figure 1. Climate division in Europe. (Source: literature review: methane from landfills methods to quantify generation, oxidation and emission, 2010) [Oonk, 2010]. 
Within the map, you can see [Romania's Climate Wikipedia, 2008] the alpine climate, the cold continental climate, the wet continental climate, and the oceanic climate.

Romania's location on the globe is: latitude between $43^{\circ} 37^{\prime} 7^{\prime \prime}$ North, with the far most point at Zimnicea and $48^{\circ} 15^{\prime} 06^{\prime \prime}$ North on Prut river at Hodoriștea, and longitude $-20^{\circ} 15^{\prime} 44^{\prime \prime}$ East at the Western side of Beba Vecheand $29^{\circ} 41^{\prime} 24^{\prime \prime}$ East on the Black Sea coast, at Sulina. Figure 2 shows the classification (distribution) of the climate on the Romanian territory. In Figure 3, there are presented the precipitation areas in Romania Territory, zones marked with letter A, B and C.

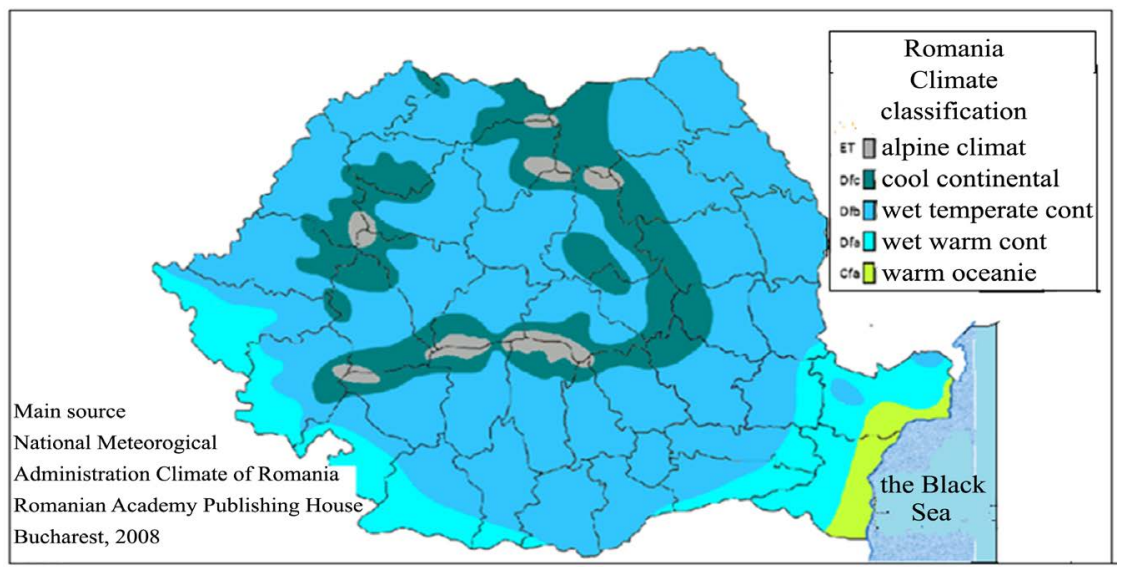

Figure 2. Climate map of Romania.

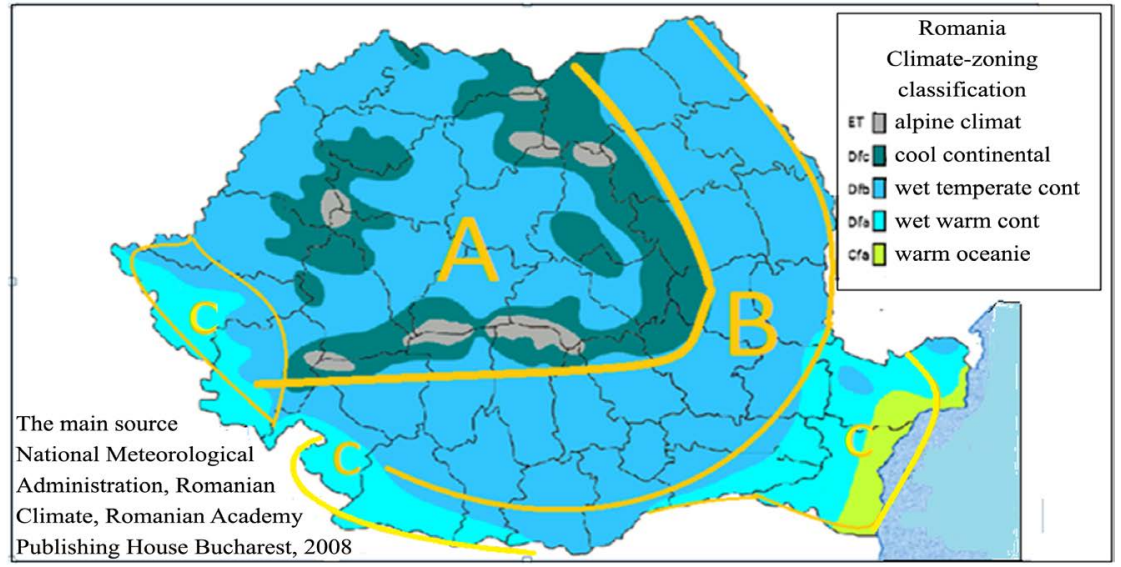

Figure 3. Map of the Precipitation areas in Romania. Zone A, precipitations of $1000 \mathrm{~mm}$ $\div 1400 \mathrm{~mm}$ /year. For Zone A, $K_{1}=0.4, K_{2}=0.39$ [Hosseini et al., 2018]; Zone B, precipitations of $600 \mathrm{~mm} \div 637 \mathrm{~mm} /$ year. For Zone B, $K_{3}=K_{4}=0.37$ [Hosseini et al., 2018]; Zone C, precipitations of $400 \mathrm{~mm} \div 500 \mathrm{~mm}$ /year. For Zone C, $K_{5}=K_{6}=0.36$ [Hosseini et al., 2018] where $K_{1}, K_{2}, K_{3}, K_{4}, K_{5}, K_{6}$ is the degradation potential of the municipal solid waste $(\mathrm{msw})$ as against the dissolved organic carbon, depending on the precipitations in the area of the municipal solid waste (msw). Calculation formula for Zone A: $K_{1}=2.79$ * $\left(10^{-4}(x)\right)+0.01, K_{2}=3.8^{*}\left(10^{-4}(x)\right)+0.01,(x)=$ precipitations in Zone A. Calculation formula for Zone B: $K_{3}=6.00015^{*}\left(10^{-4}(x)\right)+0.01, K_{4}=5.6515^{\star}\left(10^{-4}(x)\right)+0.01,(x)=$ precipitationsin Zone B. Calculation formula for Zone C: $K_{5}=8.75^{*}\left(10^{-4}(x)\right)+0.01, K_{6}$ $=7.0^{*}\left(10^{-4}(x)\right)+0.01,(x)=$ precipitations in Zone C. K can change depending on the environmental conditions (precipitations) in the area [Hosseini et al., 2018]. 


\section{Management of the Municipal Solid Waste (MSW) in Romania}

The source of the municipal solid waste (msw) in Romania's Population by Locality on January 1, 2016

[www.insse.ro/cms/ro/content/populațiaRomâniei-pe-localitati-la-1-ianuarie-20 16] is:

1) The population, divided into:

- Urban-11,350,620 inhabitants. Supposing that $1.7 \mathrm{~kg}$ municipal solid waste (msw) is generated per inhabitant per day, the total annual amount is 7043 $\mathrm{Gg} /$ year;

- Rural-8,771,021 inhabitants. Supposing that $1.1 \mathrm{~kg}$ municipal solid waste (msw) is generated per inhabitant per day, the total annual amount is $3522 \mathrm{Gg} /$ year.

2) Industrial [Voicu, 2016] (similar waste to household waste + trade + offices + agriculture and animal husbandry (agricultural processing and animal husbandry processing) + fish farming (fish processing) + human medicine and veterinary medicine that generate non-hazardous municipal solid waste (msw) that can be quantified annually. The annual amount generated is about $3120 \mathrm{Gg}$ $(600,000 \times 30 \mathrm{~kg} /$ day $\times 260$ days/year/1000/1000) where:

- 600,000 number of economic operators;

- $30 \mathrm{~kg} / \mathrm{day}-$ minimal amount of municipal solid waste (msw) generated by the economic operator;

- 260-number of days/year of activity;

- 1000 transformation, in tons, and Gg.

To the amount of $4680 \mathrm{Gg}$ municipal solid waste (msw) (similar to household waste) [generated by industrial + trade + offices + agriculture and fish farming (agricultural processing and animal husbandry processing) + fish farming (fish processing) + human medicine and veterinary medicine that generate non-hazardous municipal solid waste (msw)] we must add amounts of municipal solid waste such as: sewage sludge from towns, street sweeping, slit (that cannot be used in agriculture) from industrial and household sewage treatment plants. Estimated amount is $1500 \mathrm{Gg} /$ year.

The total amount of municipal solid waste (msw) that must be managed in an ecological-rational manner in Romania, [Voicu, 2016] is 16,745 Gg municipal solid waste $(\mathrm{msw})(7043+3522+4680+1500) /$ year $)$.

Since $15 \%$ /year represents recycling + recuperation + reutilization, it means that an amount of 14,233 Gg/year of municipal solid waste (msw) must be managed in an ecological-rational manner.

\section{Disposal of the Municipal Solid Waste (MSW) in Romania}

- Incineration, in authorized plants, to remove hazardous and potentially infectious municipal solid waste $(\mathrm{msw})$. In case of non-hazardous municipal solid waste (msw), incineration is about $4 \%, 516 \mathrm{Gg} /$ year;

- Energy recovery by economic operators in the cement industry and elec- 
tro-thermal plants. The amount used (used oil, used tires, plastic, non-recyclable paper, non-recyclable textile, non-recyclable wood) is about $900 \mathrm{Gg} /$ year;

- Landfills [Voicu, 2016] are the method most used across the world and in Romania. In 2019, there are 43 municipal solid waste landfills (MSW) authorized with Integrated Environmental Authorization out of which 3 in $\mathrm{Bu}-$ charest-Ilfov area. The 3 ones in Bucharest-Ilfov receive $1200 \mathrm{Gg}$ per year. The rest of 11,617 Gg/year of municipal solid waste (msw) need to be disposed of in 47 municipal solid waste landfills, $247 \mathrm{Gg}$ /year, authorized with Integrated Environmental Authorization or 52 municipal solid waste landfills, $223 \mathrm{Gg} /$ year, authorized with Integrated Environmental Authorization. 43 municipal solid waste landfills are not enough. $223 \mathrm{Gg} /$ year municipal solid waste (msw) disposed of in municipal solid waste landfills is a reasonable figure that ensures safe management of the LFG with $\mathrm{CH}_{4}$ content.

\section{Overview of other countries:}

- France [Meres, 2005] generated about 33,000 Gg municipal solid waste (msw) in 2011, out of which about $61 \%$ disposed of in landfills compliant with EU norms, about $25 \%$ recycled, recovered and reused, and about $14 \%$ incinerated;

- USA [Fei et al., 2015] generated about $251,000 \mathrm{Gg}$ in 2014, out of which about $56 \%$ disposed of, about $28 \%$ recycled and reused, and about $16 \%+$ incinerated.

\section{Generation of the Landfill Gas (LFG)}

The municipal solid waste (msw) is disposed of in landfills. Under the influence of the environment (temperature, freezing/defreezing periods, precipitations, snow, variation of the air pressure), physical factors (compaction of the municipal solid waste $(\mathrm{msw})$, coverage with inert material inert and soil, coverage with geotextile material and geomembranes), the landfill biodegrades and generates landfill gas (LFG).

Figure 4 presents the biodegradation of the municipal solid waste (msw), in stages [Meres, 2005], [Bellenoue et al., 2007].

\subsection{LFG Production Mechanisms and Its Evolution}

- At the beginning, the aerobic stage; the oxygen in the air retained by the municipal solid waste (msw) is consumed. The organic material decomposes into carbon dioxide [Bentley et al., 2002] [Scharff et al., 2017].

- When the oxygen is consumed, the anaerobic biodegradation begins (after covering the municipal solid waste (msw) with soil and inert material). Practically, the methanogenesis starts through cytogenesis. The $\mathrm{CH}_{4}$ content in the LFG starts increasing, but the methanogenesis is unstable [Bellenoue et al., 2007], [Prud'homme, 2001].

- The ratio $\mathrm{CH}_{4} / \mathrm{CO}_{2}$ remains stable. This stage lasts for a few decades. Then the production of $\mathrm{LFG}$ with $\mathrm{CH}_{4}$ content starts decreasing. 


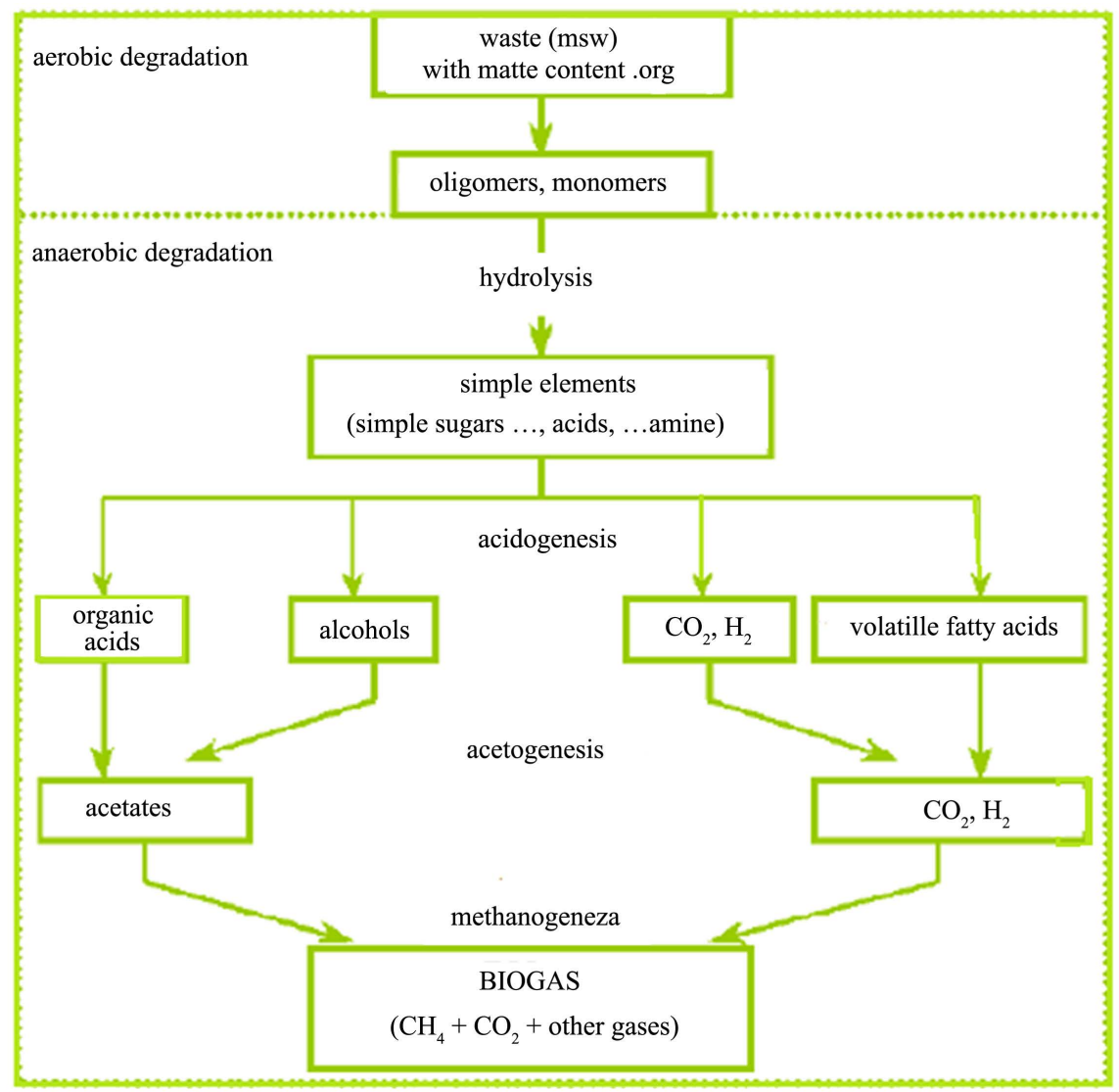

Figure 4. Biodegradation of municipal solid waste ( $\mathrm{msw}$ ) in stages: hydrolysis-acidogenesis, acetogenesis, methanogenesis. Source: Meres, 2005.

- When the LFG production becomes very low, the air starts penetrating again the landfill. If there is biodegradable material left, carbon dioxide will be generated.

The composition of the biogas varies in time. During the stable stage of methanogenesis, the $\mathrm{CH}_{4}$ content is $30 \%-60 \%$ and the $\mathrm{CO}_{2}$ content $40 \%-50 \%$, the $\mathrm{CH}_{4} / \mathrm{CO}_{2}$ ratio is therefore $1.2-1.5$, typical for this stage. Before, this ratio can reach 2 . At the end of biodegradation, this ratio decreases.

\subsection{Evolution of Methanogenesis}

\subsubsection{Initiation Stage}

It lasts from a few months to a few years. After the first aerobic stage when the oxygen retained by the municipal solid waste ( $\mathrm{msw}$ ) in the landfill is consumed, the temperature increases and carbon dioxide is produced; the methanogenesis emerges gradually. The $\mathrm{CH}_{4} / \mathrm{CO}_{2}$ ratio varies and the amount of $\mathrm{LFG}$ with $\mathrm{CH}_{4}$ content has a maximal value.

\subsubsection{Production Stage}

For decades, the methane production is stable. The $\mathrm{C} / \mathrm{N}$ ratio does not change too much. The LFG flow gradually decreases [Meres, 2005], [Bellenoue et al., 2007], [Prud'homme, 2001]. 


\subsubsection{Extinction Stage}

The LFG produced tends to zero. It is replaced by air. Methanogenesis stops. Residual biodegradation generates mainly carbon dioxide.

The main characteristics of the LFG components and the physical parameters for a mix of $60 \% \mathrm{CH}_{4}$ and $40 \% \mathrm{CQ}_{2}$ are presented in Figure 5 [Meres, 2005], [Bellenoue et al., 2007], [Prud'homme, 2001] [Guidance on the Management of Landfill Gas, 2004].

The LFG density in Romania is $0.72 \mathrm{~kg} / \mathrm{m}^{3}$.

\section{Factors That Influence the Biodegradation of the Municipal Solid Waste (MSW) in the Landfill}

\subsection{Quantity and Quality of Municipal Solid Waste (MSW) with Organic Material Content}

The LFG with $\mathrm{CH}_{4}$ content is generated as a result of physical, chemical and microbial processes that develop in the landfill of the municipal solid waste (msw).

\begin{tabular}{|c|c|c|c|c|c|c|c|c|c|c|c|c|}
\hline & \multirow{2}{*}{ Symbol } & \multirow{2}{*}{ Unit } & \multirow{2}{*}{$\mathrm{CH}_{4}$} & \multirow{2}{*}{$\mathrm{CO}_{2}$} & \multirow{2}{*}{$\mathrm{O}_{2}$} & \multirow{2}{*}{$\mathrm{N}_{2}$} & \multirow{2}{*}{ Air } & \multirow{2}{*}{$\mathrm{H}_{2} \mathrm{O}$} & \multirow{2}{*}{$\mathrm{H}_{2} \mathrm{~S}$} & \multicolumn{3}{|c|}{ Mixture containing $\mathrm{CH}_{4}$} \\
\hline & & & & & & & & & & $20 \%$ & $40 \%$ & $60 \%$ \\
\hline molecular mass & M & $\mathrm{g} / \mathrm{mol}$ & 456.00 & 44.01 & 32.00 & 28.01 & 28.96 & 18.02 & 34.08 & 28.25 & 27.98 & 26.42 \\
\hline volumic mass & $\mathrm{r}$ & $\mathrm{kg} / \mathrm{Nm}^{3}$ & 0.72 & 1.98 & 1.43 & 1.25 & 1.29 & 0.86 & 1.54 & 1.27 & 1.25 & 1.19 \\
\hline density & d & $"$ & 0.56 & 1.53 & 1.11 & 0.97 & 1.00 & 0.67 & 1.19 & 0.98 & 0.97 & 0.92 \\
\hline mass thermal capacity & $\begin{array}{c}\mathrm{Cp} \text { at } \\
0^{\circ} \mathrm{C}\end{array}$ & $\mathrm{kJ} / \mathrm{kg} . \mathrm{K}$ & 2.15 & 0.82 & 0.91 & 1.04 & 1.00 & 1.89 & 1.00 & 1.23 & 1.43 & 1.65 \\
\hline $\begin{array}{c}\text { kinemticvascosity } \\
\text { at } 20^{\circ} \mathrm{C}\end{array}$ & $20^{\circ} \mathrm{C}$ & $\mu$ Pa.s & 11.19 & 15.34 & 19.92 & 16.95 & 17.08 & 9.01 & 12.4 & 15.70 & 14.08 & 12.66 \\
\hline $\begin{array}{l}\text { compresibility } \\
\text { factor }\end{array}$ & $\mathrm{Z}$ & & 1.00 & 0.99 & 1.00 & 1.00 & 1.00 & 0.93 & 0.99 & 1.00 & 0.99 & 0.99 \\
\hline critical pressure & $\mathrm{Pc}$ & bar & 46.00 & 73.90 & 50.40 & 33.90 & 37.70 & 220.60 & 89.40 & 50.15 & 57.39 & 61.53 \\
\hline critical temperature & $\mathrm{Tc}$ & $\mathrm{K}$ & 190.50 & 304.50 & 154.60 & 126.20 & 132.45 & 647.10 & 373.20 & 185.52 & 223.19 & 246.23 \\
\hline politropic index & gamma & & 1.31 & 1.31 & 1.40 & 1.40 & 1.40 & 1.40 & 1.30 & 1.37 & 1.34 & 1.31 \\
\hline high caloric value & $\mathrm{PCSm}$ & $\mathrm{MJ} / \mathrm{kg}$ & 55.66 & & & & & & 16.52 & 11.15 & 22.28 & 33.41 \\
\hline $\begin{array}{c}\text { volumetric calorific } \\
\text { value }\end{array}$ & $\mathrm{PCSV}$ & $\mathrm{MJ} / \mathrm{m}^{3}(\mathrm{n})^{(1)}$ & 39.82 & & & & & & 25.37 & 7.99 & 15.95 & 23.92 \\
\hline lower caloric value & PClm & $\mathrm{MJ} / \mathrm{kg}$ & 50.04 & & & & & & 15.19 & 10.02 & 20.03 & 30.04 \\
\hline $\begin{array}{c}\text { lower caloric value by } \\
\text { volume }\end{array}$ & $\mathrm{PClv}$ & $\mathrm{MJ} / \mathrm{m}^{3}(\mathrm{n})$ & 35.88 & & & & & & 23.33 & 7.20 & 14.38 & 21.55 \\
\hline Wobbe index & W & $\mathrm{MJ} / \mathrm{m}^{3}(\mathrm{n})$ & 153.41 & & & & & & 23.28 & 10.71 & 21.39 & 32.07 \\
\hline $\begin{array}{c}\text { pommercial }^{(2)} \\
\text { potential }\end{array}$ & Lmin & $m^{3}(n) / m^{3}(n)$ & 9.57 & & & & & & 7.23 & 1.22 & 3.43 & 5.71 \\
\hline $\begin{array}{l}\text { the volume of }{ }^{(3)} \\
\text { wet smoke }\end{array}$ & Vgb.h & $m^{3}(n) / m^{3}(n)$ & 10.52 & & & & & & 7.70 & 1.91 & 3.58 & 5.75 \\
\hline \multicolumn{13}{|c|}{ (1) $\mathrm{m}^{3}(\mathrm{n}) \mathrm{m}^{3}$ normal at $1 \mathrm{~atm}$. and $0^{\circ} \mathrm{C}$; } \\
\hline \multicolumn{13}{|c|}{ (2) commercial potential $\mathrm{m}^{3}$ combustion air $/ \mathrm{m}^{3}$ of combustible gas in stoichiometric conditions; } \\
\hline \multicolumn{13}{|c|}{ (3) volume of wet smoke $\mathrm{m}^{3}$ of smoke $/ \mathrm{m}^{3}$ combustible gasin stoichiometric conditions; } \\
\hline
\end{tabular}

Figure 5. Physical characteristics and energy characteristics of the LFG components for a mix of $60 \% \mathrm{CH}_{4}$ and $40 \% \mathrm{CO}_{2}$. Source: Gerer le gaz de decharge Techniques et recommendations, 2001. 
Due to the organic nature of most municipal solid waste (msw), the microbial process generates gas-LFG. [Guidance on the Management of Landfill Gas, 2004], [Conestoga-Rovers \& Associates, 2010], [Isin, 2013] [International Best Practices Guide for LFGE Projects, 2012]. This process is sensitive to its environment, therefore certain natural and artificial conditions will affect the microbial population and the flow of the LFG generated. The short term research on the big municipal solid waste landfills using data from LFG extraction tests indicate LFG generation flows between $0.05-0.40 \mathrm{~m}^{3} \mathrm{LFG} / \mathrm{kg}$ municipal solid waste (msw) in landfills. The amount of the municipal solid waste (msw) is the solid material $(75 \%-80 \%)$, and humidity $(25 \%-20 \%)$. This range is a function of the organic content of the municipal solid waste (msw) in the landfill.

The LFG generation takes place in anaerobic conditions and all natural or artificial conditions that turn the process into anaerobic will affect the LFG generation. To note that the LFG generation is not instantaneous; all amounts of municipal solid waste (msw) brought to a landfill will be subject to the processes presented in Figure 4 and Figure 6.

As Figure 4 shows, the first stage, the aerobic biodegradation, takes place right after the disposal of the municipal solid waste (msw) due to the oxygen in the municipal solid waste $(\mathrm{msw})$. Anaerobic biodegradation produces carbon dioxide, water and heat until the oxygen in the waste is consumed. The next stage is the anoxic, non-methanogenous stage, when acid chemical components and hydrogen are formed, while carbon dioxide is being generated; in general, this is a hydrolysis and cytogenesis process.

The environmental factors, during this stage of fragmentation of big molecules into small molecules such as ammonia, carbon dioxide, hydrogen, water and heat, consumes the residual oxygen and the nitrogen resulted from the municipal solid waste (msw) [Guidance on the Management of Landfill Gas, 2004], [Conestoga-Rovers \& Associates, 2010], [Isin, 2013].

Diagram of the evolution of the gaseous of landfill (msw)

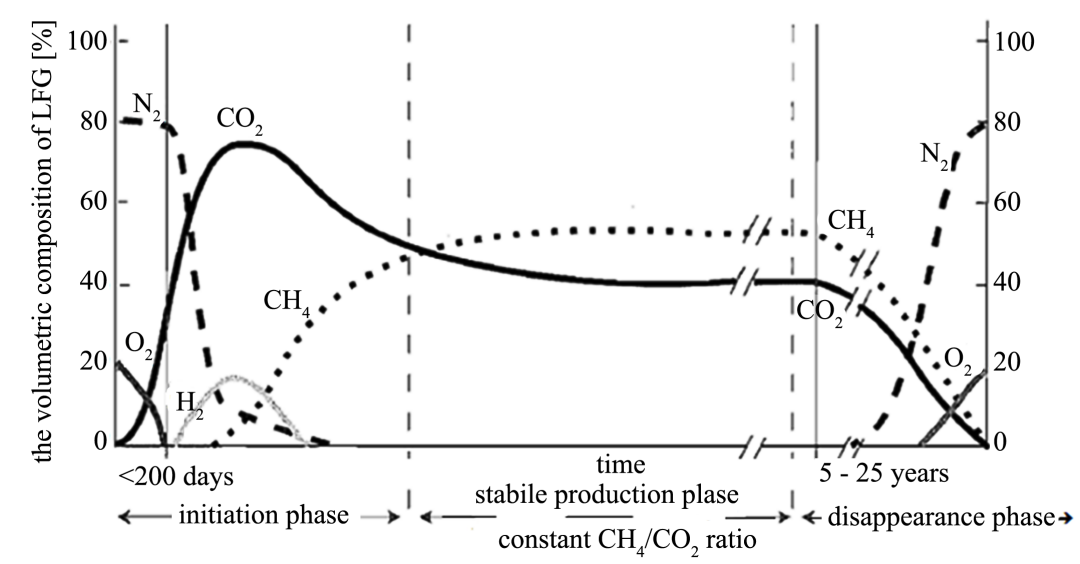

Figure 6. Graph of the evolution of gas composition per stages of biodegradation in a municipal solid waste landfill. Source: Gerer le gaz de decharge Techniques et recommandations, 2001. 
The third stage is the unsafe methanogenic stage. The generation of carbon dioxide decreases, because the biodegradation of the municipal solid waste (msw) turns from aerobic stage into anaerobic stage. The anaerobic biodegradation results in heat and water, and, unlike the anaerobic process of decomposing, results in methane, too.

The methanogenic bacteria are active during this stage, and they use the secondary products of the previous stage, the methane production.

During the fourth stage, methane is generated with a concentration between $35 \%-65 \%$ out of the total volume [Guidance on the Management of Landfill Gas, 2004], [Conestoga-Rovers \& Associates, 2010], [Isin, 2013]; the processes responsible for methane generation are generally stable. The biodegradation of the municipal solid waste (msw), in most landfills, reaches the stable stage in less than 2 years from the disposal of the municipal solid waste (msw). To note, however, the importance of the local environmental conditions (temperature and humidity, precipitations, air pressure variation, air movement above the landfill).

\subsection{Composition of the Municipal Solid Waste (MSW)}

The composition of the municipal solid waste ( $\mathrm{msw}$ ) is the major factor to estimate the potential to generate LFG and the total yield of the municipal solid waste landfill. The maximal potential volume of LFG depends on the amount and on the type of organic material in the municipal solid waste (msw) [Guidance on the Management of Landfill Gas, 2004], [Conestoga-Rovers \& Associates, 2010], [Isin, 2013], since the organic material in the municipal solid waste (msw) that decomposes is the main source of LFG with $\mathrm{CH}_{4}$ content.

Inorganic and inert material will produce less or zero LFG with $\mathrm{CH}_{4}$ content; more municipal solid waste (msw) with organic content will produce more LFG with $\mathrm{CH}_{4}$ content on kilo. The municipal solid waste (msw) with high content of organic material, such as food waste, and sludge generate high amounts of LFG, but they contain water fractions that do not produce LFG but increase the LFG flow. In terms of humidity, there is a threshold above which the LFG generation decreases [Guidance on the Management of Landfill Gas, 2004], [Conestoga-Rovers \& Associates, 2010], [Isin, 2013].

\subsection{Humidity Content}

The percentage of moisture in the landfill (msw) is considered to be one of the most important parameters that control the flow rate of LFG; moisture provides the aqueous environment needed to generate LFG and also serves as a mean of transport for the nutrients and bacteria.

In Romania, the annual average of precipitations, [Romania's Climate Wikipedia, 2008] following the gradual decrease of oceanic and Mediterranean influences, decreases slightly from west to east. The annual average of precipitations (calculated throughout the territory) is of $637 \mathrm{~mm}$ per year, with significantly higher values in the mountain areas (1000 - $1400 \mathrm{~mm}$ /year, (Stâna de Vale resort 
is considered the "rain pole in Romania")) and progressively lower towards the east, in Bărăgan being below $500 \mathrm{~mm} /$ year, in Dobrogea and the Danube Delta falling below $400 \mathrm{~mm}$ /year [Romania's Climate Wikipedia, 2008].

\section{New Calculation Method to Estimate the $\mathrm{CH}_{4}$ Emission in the Municipal Solid Waste Landfill in Romania, Author: Danila Vieru Msc., Chemistry}

Figure 7 presents the biodegradationof the municipal solid waste (msw) at an active landfill and at a landfill where the disposal of the municipal solid waste (msw) has ended.

If one type of municipal solid waste does not reach the landfill, it can be removed from the calculation program.

Annually, part of the municipal solid waste (msw) at a landfill is biodegraded down to dissolved organic carbon and part of it remains non-biodegraded. Biodegradationtakes place in a number of months - $m$ - between 2 successive disposals at the landfill according to NOMOGRAMAVieru ${ }^{\circledR}$ (see Figure 7).

Clarification: biodegradation of the municipal solid waste ( $\mathrm{msw}$ ) in the landfill takes place during the lifetime of the landfill and until exhaustion of the organic material contained in the municipal solid waste (msw) [Atabi et al., 2014].

The disposal of the municipal solid waste ( $\mathrm{msw}$ ) is based upon few principles:

- The municipal solid waste (msw) is disposed of, after sorting, in the random landfill, so all kinds of waste come in contact with each other [Scharff, Jacobs et al., 2006] [Hosseini et al., 2018] [Jacobs et al., 2001];

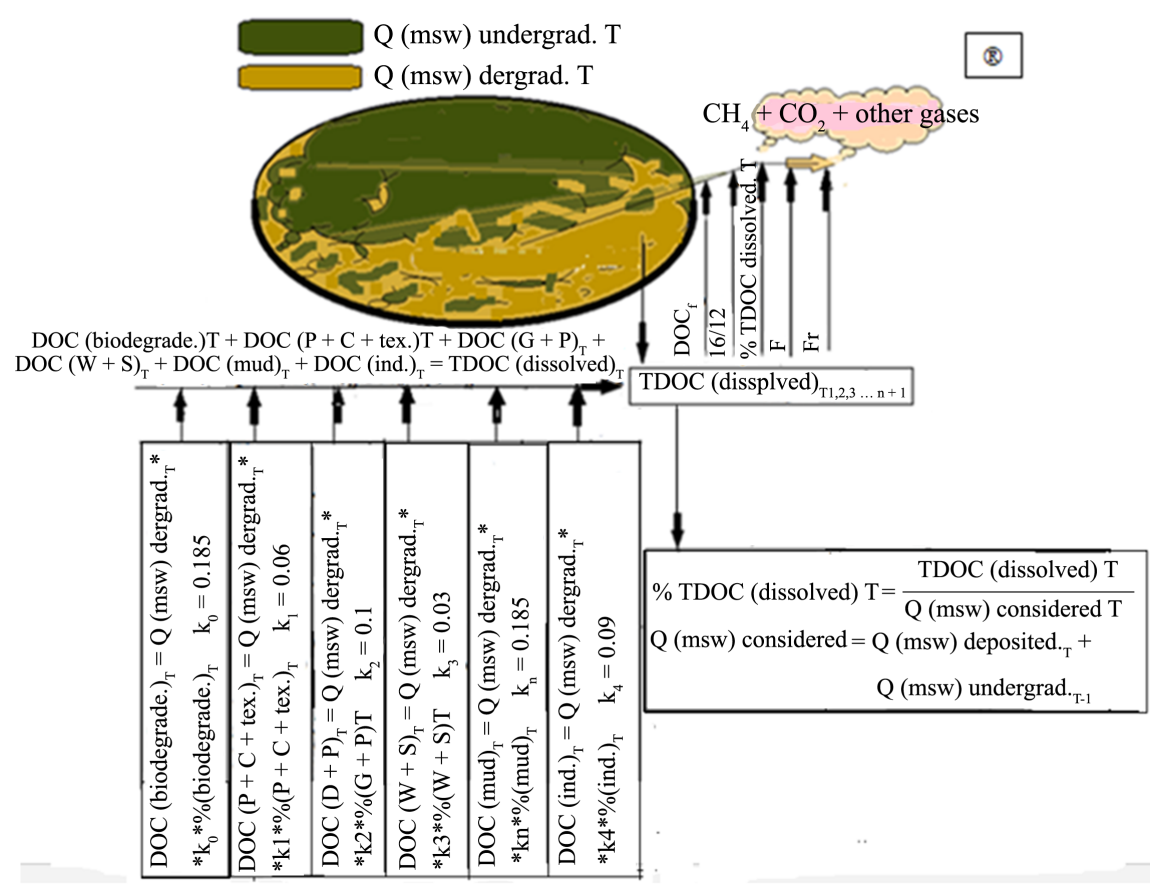

Figure 7. The working algorithm ${ }^{\circledR}$ to estimate the $\mathrm{CH}_{4}$ emission in the LFG, at an active landfill of municipal solid waste ( $\mathrm{msw}$ ), given the 7 types of municipal solid waste ( $\mathrm{msw}$ ) that can penetrate the landfill of municipal solid waste. 
- Based on the recommendations of the IPCC experts, 7 kinds of waste have been identified with a certain degradation rate expressed by factor $\mathrm{k}$ [Word Press.com, 2014], [Pipatti \& Svardal, 2006], [Godlove et al., 2018] [Peer et al., 1992].

- The LFG emission with $\mathrm{CH}_{4}$ content, for the reference year, is due to the amount of municipal solid waste (msw) biodegraded down to dissolved organic carbon [Ludwig et al., 2010].

- The amount of biodegraded waste for the reference year includes the pre-established percentage of municipal solid waste (msw) in the landfill. Table 1 presents the pre-established percentages of the types of municipal solid waste $(\mathrm{msw})$ in the landfill. This composition is retained in the amount of municipal solid waste (msw) degraded in the reference year.

- With data collected from stakeholders involved in the management of the municipal solid waste (msw), we can establish the percentages in the municipal solid waste landfill [Voicu, Vieru et al., 2019]. The composition can be maintained up to 5 years or it can be changed annually, depending on socio-economic circumstances. The statistics of the municipal solid waste (msw) plays major role in establishing the percentages in the municipal solid waste landfill (see Table 1).

- The disposal of the municipal solid waste $(\mathrm{msw})$ is done for the 12-month calendar year when they are leveled and compacted [Word Press.com, 2014].

Table 1. Chitila-Rudeni-Iridex municipal solid waste landfill-pre-established percentages of municipal solid waste (msw) in the landfill.

\begin{tabular}{|c|c|c|c|c|c|}
\hline \multicolumn{6}{|c|}{ Municipal solid waste (msw) in the landfill, for the reference year, Between 2000-2011, (\%) } \\
\hline 51.2 & 16 & 16.8 & 3 & 1 & 12 \\
\hline $\begin{array}{l}\text { Biodegradable municipal } \\
\text { solid waste (msw) (food, } \\
\text { animal farming, agriculture, } \\
\text { street sweeping etc.) }\end{array}$ & $\begin{array}{l}\text { Municipal } \\
\text { solid waste } \\
(\mathrm{msw})(P+G)^{* *}\end{array}$ & $\begin{array}{l}\text { Municipal solid } \\
\text { waste }(\mathrm{msw}) \\
(\mathrm{P}+\mathrm{C}+\text { tex })^{* * *}\end{array}$ & $\begin{array}{l}\text { Municipal solid } \\
\text { waste }(\mathrm{msw}) \\
\text { (wood }+ \text { straw) }\end{array}$ & $\begin{array}{l}\text { Sludge (sewage } \\
\text { cleansing, Sludge } \\
\text { from treatment plants) }\end{array}$ & $\begin{array}{l}\text { Industrial municipal } \\
\text { solid waste (similar } \\
\text { to household + sterile } \\
\text { medical waste) }\end{array}$ \\
\hline
\end{tabular}

Municipal solid waste (msw) in the landfill in the reference year, For 2012, (\%)

58

13.8

10.7

Biodegradable municipal solid waste (msw) (food, animal farming, agriculture, street sweeping etc.)
Municipal solid

$\begin{array}{ll}\text { Municipal } & \text { Municipal solid } \\ \text { solid waste } & \text { waste } \\ (\mathrm{msw})(\mathrm{P}+\mathrm{G})^{\star *} & (\mathrm{msw}) \\ & (\mathrm{P}+\mathrm{C}+\mathrm{tex})^{\star * *}\end{array}$

Municipal solid waste (msw) $($ wood + straw $)$
1.5

Sludge (street sweeping, sewage cleansing, sludge from treatment plants)

Municipal solid waste (msw) in the landfill in the reference year, Between 2013-2016, (\%)

60

14.4

14.2

Biodegradable municipal solid waste(msw) (food, animal farming, agriculture, street sweeping etc.)
Municipal

$\begin{array}{ll}\text { Municipal } & \begin{array}{l}\text { Municipal } \\ \text { solid waste } \\ \text { solid waste }\end{array} \\ (\mathrm{msw})(\mathrm{P}+\mathrm{G})^{* *} & (\mathrm{P}+\mathrm{C}+\mathrm{tex})^{* * *}\end{array}$

1.4

Municipal solid waste (msw) $($ wood + straw $)$
Sludge (street sweeping, sewage cleansing, sludge from treatment plants)
Industrial municipal solid waste (similar to household + Sterile medical municipal solid waste)

${ }^{* *}(\mathrm{P}+\mathrm{G})$ municipal solid wastefrom parks and gardens; ${ }^{* * *}(\mathrm{P}+\mathrm{C}+$ tex $)$ municipal solid waste from paper + cardboard + textile. 
- Vertical- $\mathrm{A}_{\mathrm{C}}$-is the calendar year when the disposal is done, practically the height-(h) of the municipal solid waste landfill on the vertical that includes coverage with low permeability material.

- Vertical- $\mathrm{A}_{\mathrm{T}}$-is the year when the amount of municipal solid waste (msw) biodegraded to DOC (dissolved organic carbon) lower with 6 months than the calendar year.

- Estimation of the amount $\mathrm{f}$ municipal solid waste (msw) degraded down to DOC (dissolved organic carbon), in the reference year, that generates $\mathrm{CH}_{4}$ emissions annually starts with the $2^{\text {nd }}$ calendar year after the municipal solid waste $(\mathrm{msw})$ is disposed of; the first year of calculation $-\mathrm{A}_{\mathrm{T}}-1$ is the first 6 months after the beginning of the disposal [Barlaz et al., 2012].

- Each year, there is an amount of non-degraded municipal solid waste (msw) in the municipal solid waste landfill that is taken into account for calculation in the following year.

- The LFG with $\mathrm{CH}_{4}$ content, on its way to the cover of the municipal solid waste landfill or to the extraction-collection well, will collect all incipient gases.

- A NOMOGRAMA Vieru ${ }^{\circledR}$ can be allocated to each municipal solid waste landfill, as seen in Figure 8.

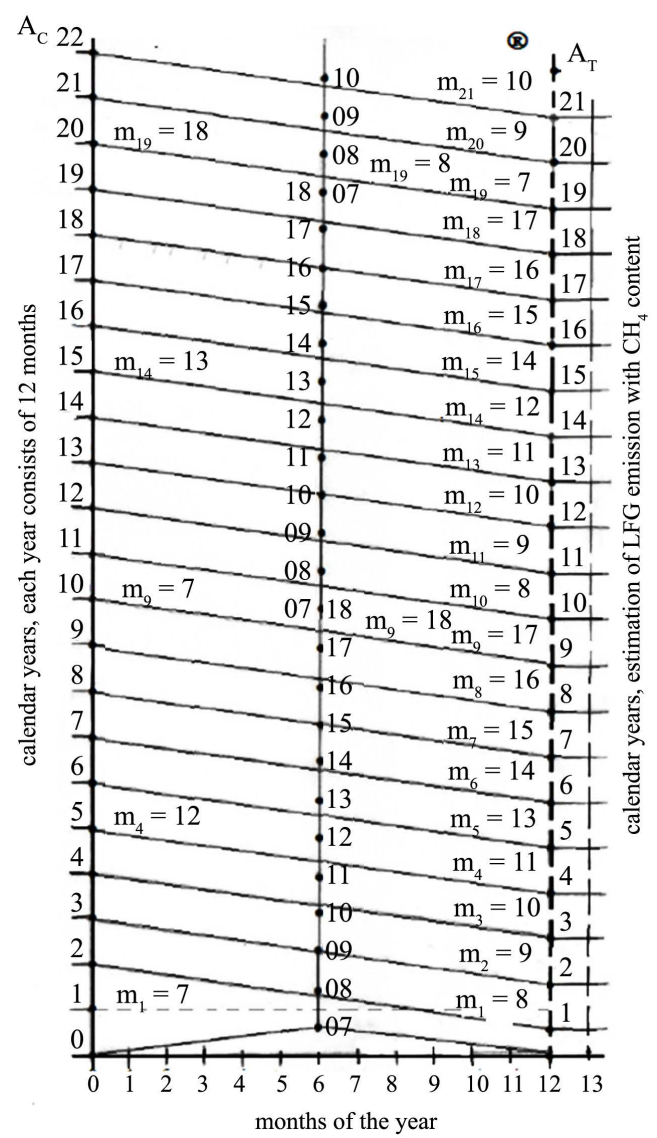

Figure 8. NOMOGRAMA Vieru ${ }^{\circledR}$ of a municipal solid waste landfill. NOMOGRAMA Vieru $^{\circledR}$. 
- Landfills that collect LFG with $\mathrm{CH}_{4}$ content shall send the information to the environmental authority.

- Landfills that do not collect LFG should know when they introduce the extraction-collection system as they needn't pay environmental taxes.

\subsection{NOMOGRAMA Vieru ${ }^{\circledR}$ of a Municipal Solid Waste Landfill}

Aspects of NOMOGRAMA Vieru ${ }^{\circledR}$ of a municipal solid waste landfill (see Figure 8):

- $A_{O}$ to the left, is the number of calendar years of the municipal solid waste landfill. A calendar year has 12 months. As a rule, the life time of a municipal solid waste landfill is 20 - 30 years, but we can also have municipal solid waste landfills of 40 - 50 years. $A_{C^{-1}}$ is the year when the disposal of the municipal solid waste (msw) begins.

- $A_{T}$, to the right, is the number of years of calculation regarding the estimation of $\mathrm{CH}_{4}$ emission. Due to the practical observations according to which the beginning of the LFG emission with $\mathrm{CH}_{4}$ content is delayed with approx. 6 months since the beginning of the disposal and to the fact that it has been agreed that: municipal solid waste(msw) disposed of between $01.07-31.12$. remained non-degraded, for the $6^{\text {th }}$ month, there have been given, on the vertical, solutions for the equation of a municipal solid waste landfill $3 m+7=$ $13-m, m \in \mathrm{N}, 7 \leq m \leq 12$ [Mihoc et al., 1980] or after the first year of disposal but after the end of the $2^{\text {nd }}$ calendar year $[(3+8 n) m+7=(12 n+13)-m], m \in \mathrm{N}, 7 \leq m \leq 18$.

- By connecting the points on $A_{T}$ with the points on $A_{C}$ at the intersection of the line of the solutions of the equation $(3+8 n) m+7=(12 n+13)-m \quad{ }^{*}, 7$ $\leq m \leq 18$, [Vieru, 2017a: pp. 436-454], [Vieru, 2017b: pp. 191-209] we find the number of months during which the degradation of an amount of municipal solid waste $(\mathrm{msw})$ for the reference year takes place. The use of NOMOGRAMA Vieru ${ }^{\circledR}$ requires a lot of expertise.

- Horizontal, the calendar year has 12 months, the municipal solid waste landfills are leveled, compacted and covered with inert material. Month 13 appears because, after the end of the calendar year, 1 more month is needed to collect information about the municipal solid waste landfill analyzed. The information consists of: the amount of municipal solid waste disposed of in the landfill in the calendar year that has ended, the amount of LFG with $\mathrm{CH}_{4}$-content ( $\mathrm{m}^{3}$ or $\mathrm{Gg}$.) - collected in the calendar year that has ended, whether a LFG extraction-collection system has been implemented, the $\mathrm{CH}_{4}$ (\%) concentration, the number of vertical wells to collect LFG, the existence of a horizontal LFG extraction-collection system, the management of the leach ate, the pressure (mbar) of the LFG extraction-collection system, the variation of the air pressure $(\mathrm{mm} \mathrm{Hg})$, the temperature in the area of the municipal solid waste landfill, the precipitation periods, the amounts of sludge from treatment plants, $[\mathrm{Gg}]+$ amounts of sludge from sewage cleansing $[\mathrm{Gg}]$, the amounts of municipal solid waste from parks and gardens $(\mathrm{P}+$ $\mathrm{G})$ including cemeteries $[\mathrm{Gg}]$, the amounts of industrial municipal solid 
waste (similar to household municipal solid waste) $[\mathrm{Gg}]$, amounts of sterile-ground medical municipal solid waste $[\mathrm{Gg}]$, amounts of straw and wood municipal solid waste $[\mathrm{Gg}])$.

\subsection{Regarding the Equation ${ }^{\circledR}$ of a Municipal Solid Waste Landfill}

The equation of a municipal solid waste landfill after replacing $x$ with $t$ is $3 t+7=13-t{ }^{\circledR}$ [Mihoc et al., 1980], which is $(3+8 n) \cdot t+7=(12 n+13)-t{ }^{\circledR} *$ [Vieru, 2017a: pp. 436-454], [Vieru, 2017b: pp. 191-209] after the first year, where $t$ is the biodegradation time of the municipal solid waste (msw) in the landfill and can be replaced with $m$ because $t$ can only be expressed in number of months- $m$; it cannot be expressed in seconds, minutes, days, years.

The equation $[3+(n * 8)] * t+7=[(n * 12)+13]-t$, $\mathbb{B}[$ Vieru, 2017a: pp. 436-454; Vieru, 2017b: pp. 191-209] or $[3+(n * 8)] * t+7=[(n * 12)+(12+1)-t] \quad{ }^{\circledR} *$ [Vieru, 2017a: pp. 436-454], [Vieru, 2017b: pp. 191-209] expresses: if we add 7 to 3 times the time $t$, expressed by a number of months - $m$ - of stationary municipal solid waste (msw) at a location in the landfill-is the same with deducting a time $t$ (expressed by a number of months - m-) from 25.

In the above equation:

$n$ is the number of the calendar year of disposal;

12-number of the calendar months of the year of disposal;

1 in $(12+1)$ is 1 month needed to collect information regarding the municipal solid waste landfill analyzed;

$t$-time during which the municipal solid waste was stationary at the location in the landfill, expressed by the number of months - $m$-.

For each year of disposal, starting with the $2^{\text {nd }}$ year, the equation changed its terms but mathematically it will always have a unique solution $3 / 2$.

The number of month's $-m$ - is defined for each reference year when it shall fulfill the condition:

1) $7 \leq m \leq 18, m \in \mathrm{N}$, [Vieru, 2017a: pp. 436-454], [Vieru, 2017b: pp. 191-209]

2) $\sum\left(m_{1}+m_{2}+m_{3}+\cdots+m_{n+1}\right) \leq[(n * 12)+13]-7,{ }^{\circledR} \quad[$ Vieru, 2017a: pp. 436-454]

Based on NOMOGRAMAVieru ${ }^{\circledR}$, presented in Figure 7, for the reference year, we can establish the number of month's - $m$ - (during which a certain amount of municipal solid waste (msw) degraded down to DOC (dissolved organic carbon).

\subsection{Definition of Parameter $m$}

$m$ is the number of months during which maximum $45 \%$ of the municipal solid waste (msw) disposed or taken into account degrades at the landfill.

\subsection{NOMOGRAMA of a Municipal Solid Waste Landfill}

The calendar years and the years of calculation result from replacing $1,2,3, \ldots$, 
20, ..., 30 with the years 1992, 1993, 1994, 2011, 2012, 2013, .., 2025, ..., 2030.

(R) means that, in Romania, the calculation kit to estimate the $\mathrm{CH}_{4}$ emission from municipal solid waste landfills, the equation of a municipal solid waste landfill, NOMOGRAMA of a municipal solid waste landfill-NOMOGRAMA Vieru ${ }^{\circledR}$-, and the working algorithm to estimate the emission of the $\mathrm{CH}_{4}$ contained in the LFG are registered with ORDA (the Romanian Office for Intellectual Rights) on the name of Danila Vieru. Any other concerns or questions may be submitted via e-mail to danila.vieru@gmail.com. The calculation formula to estimate the $\mathrm{CH}_{4}$ emission in the municipal solid wasteland fills in Romania can be applied to other countries with similar environmental conditions.

\subsection{Equation of a Municipal Solid Waste Landfill}

1) For a municipal solid waste landfill where the disposal of the municipal solid waste has ended, we can write the equation:

$$
3 t+7=13-t
$$

where $t$ is the time (expressed in number of months $-m-$ ) during which, for the reference year- $T$-of the emission of LFG with $\mathrm{CH}_{4}$ content a certain amount of municipal solid waste (msw) degrades $-Q_{\text {mswdegradat }, T}$ down to DOC which generates LFG with $\mathrm{CH}_{4}$ content. The calculation range for the amount of municipal solid waste $Q_{\mathrm{mswdegadat}, T}$ is $m=6$. Annually, for each $m=6$, the $Q_{\mathrm{msw}, T}$ degraded down to DOC will be calculated. The reason of this calculation is: the municipal solid waste (msw) disposed of degrades down to DOC depending on the environmental conditions at the location of the landfill and there is no other municipal solid waste (msw) disposed to influence the LFG emission. For $m=6$, the repetitive calculation will lead to zero emission at the landfill analyzed and implicitly the entire amount of municipal solid waste (msw) degraded down to DOC. The amounts of municipal solid waste consisting of plastic material with very long degradation time that form carbon deposits are not taken into account in this calculation.

2) For an operational municipal solid waste landfill (receiving, annually, a certain amount of municipal solid waste $(\mathrm{msw})$ ), the following equation shall be written:

$$
(3+8 n) t+7=(12 n+(12+1))-t
$$

where $t$ is the time (expressed by a number of months $-m_{-}^{-}$) during which, in the reference year -T-, a certain amount of municipal solid waste (msw) degrades $-Q_{\text {mswdegradat } T^{-}}$down to DOC (dissolved organic carbon) which will generate LFG with $\mathrm{CH}_{4}$ content. For the reference year - $T$ - of the emission of LFG with $\mathrm{CH}_{4}$ content, it remains an amount of non-degraded municipal solid waste (msw) disposed of during the last 6 months $(01.07$ - 31.12) of the year when it was disposed of. The municipal solid waste that remains non-degraded in the reference year - $T$ - shall be taken into account for the next year (see the working algorithm Figure 7). 
The mathematical equation and the other equations that clarify the estimation of the $\mathrm{CH}_{4}$ emission at the municipal solid waste landfills in Romania can be written as follows [Vieru, 2017a: pp. 436-454], [Vieru, 2017b: pp. 191-209]:

$$
\begin{aligned}
& \mathrm{CH}_{4}(\mathrm{Gg} / \text { year })_{T}=Q_{\text {mswdegrad }, T} * \% \mathrm{TDOC}_{\text {dissolved }, T} * \mathrm{DOC}_{\mathrm{f}} * 16 / 12 * F * F_{r} \text {, }{ }^{\circledR} * \\
& Q_{\mathrm{mswdegrad}, T}=\left(Q_{\mathrm{msw}, T}+Q_{\mathrm{msw}, T-1}\right) *[1-\exp (-K t)]^{\circledR *}[\mathrm{Gg}] \\
& Q_{\mathrm{mswdegrad}, T}=\left(Q_{\mathrm{msw}, T}+Q_{\mathrm{mswundegra}, T-1}\right) *[1-\exp (-K t)]^{\circledR *}[\mathrm{Gg}] \\
& Q_{\mathrm{mswundegrad}, T}=\left(Q_{\mathrm{msw}, T}+Q_{\mathrm{msw}, T-1}\right)-Q_{\mathrm{mswdegrad}, T}{ }^{\circledR *}[\mathrm{Gg}] \\
& \mathrm{TDOC}_{\text {dissolved }, T}=\Sigma[A+B+C+D+E+G]^{\circledast *}[\mathrm{Gg}] \\
& A=Q_{\mathrm{mswdegrad}, T} * \% Q_{\mathrm{mswbiodegrad}, T} * k_{0},{ }^{\circledR *}[\mathrm{Gg}] \\
& B=Q_{\mathrm{mswdegrad}, T} * \% Q_{\mathrm{msw}(\mathrm{G}+\mathrm{P}) \operatorname{degrad}, T} * k_{1},{ }^{\circledR *}[\mathrm{Gg}] \\
& C=Q_{\mathrm{mswdegrad}, T} * \% Q_{\mathrm{msw}(\mathrm{H}+\mathrm{C}+\text { text. }) \text { degrad }, T} * k_{2},{ }^{\circledR *}[\mathrm{Gg}] \\
& D=Q_{\text {mswdegrad }, T} * \% \mathrm{Msw}_{(\text {wood }+ \text { straw }) \text { degrad }, T} * k_{3},{ }^{\circledR}[\mathrm{Gg}] \\
& E=Q_{\text {mswdegrad }, T} * \% \mathrm{msw}_{\text {sludg.degrad }, T} * k_{n},{ }^{\circledR *}[\mathrm{Gg}] \\
& \left.G=Q_{\mathrm{mswdegrad}, T} * \% Q_{\mathrm{mswind.degrad}, T} * k_{4},{ }^{\circledR} * \mathrm{Gg}\right] \\
& \% \mathrm{TDOC}_{\text {dissolved }, T}=\left(\mathrm{TDOC}_{\text {dissolved }, T}\right) /\left(Q_{\mathrm{mswtakenintoconsid}, T}\right)^{\circledR *}[\mathrm{Gg}] \\
& Q_{\text {mswtakenintoconsid }, T}=Q_{\mathrm{msw}, T}+Q_{\text {mswundergrad }, T-1},{ }^{\circledR *}[\mathrm{Gg}]
\end{aligned}
$$

where:

$Q_{\mathrm{msw}, T}-$ amount of municipal solid waste (msw) disposed of in the year $T$, $[\mathrm{Gg}]$

$Q_{\mathrm{msw}, T-1}$-amount of municipal solid waste (msw) disposed of in the year $T_{1}$, $[\mathrm{Gg}]$

$Q_{\text {mswdegrad. T }}$ amount of municipal solid waste (msw) degraded in the reference year regarding the estimation of the $\mathrm{CH}_{4}$ emission [Gg];

$Q_{\text {mswundegrad.T-amount of municipal solid waste (msw) remained non-degraded }}$ in the year of calculation, $[\mathrm{Gg}]$;

$Q_{\text {mswundegrad,T-1 }}$-amount de municipal solid waste (msw) remained non-degraded in the year $T-1$, taken into account to calculate \%TDOC, [Gg];

$\mathrm{K}$-degradation rate of the municipal solid waste (msw) disposed of that contain types of municipal solid waste (msw) in the landfill, in percentages [Vieru, 2017a: pp. 436-454], [Vieru, 2017b: pp. 191-209]; value of K for Romaniais defined depending on the rain water in the area if the landfill as well as other environmental conditions.

$T$-time expressed by the number of month's - $m$-. It can be expressed by the formulas: $\left[\frac{13-m}{12}\right]$ or $\left[\frac{25-m}{12}\right]$;

$Q_{\text {mswbiodegrad. }} \%$ of biodegraded municipal solid waste (msw) from the amount of municipal solid waste (msw) degraded in the year $T$;

$Q_{\mathrm{msw}(\mathrm{G}+\mathrm{P})}-\%$ of municipal solid waste of $(\mathrm{G}+\mathrm{P})$ from the amount of munici- 
pal solid waste (msw) degraded in the year $T$;

$Q_{\mathrm{msw}(\mathrm{P}+\mathrm{C}+\mathrm{tex})}-\%$ of municipal solid waste $(\mathrm{P}+\mathrm{C}+$ tex $)$ from the amount of municipal solid waste (msw) degraded in the year $T$;

$Q_{\text {msw(wood+straw) }}-\%$ of municipal solid waste (wood + straw) from the amount of municipal solid waste (msw) degraded in the year $T$;

$Q_{\text {mswsludg. }}$ \% of sludge from the amount of municipal solid waste (msw) degraded in the year $T$;

$Q_{\text {mswind. }}$ \% of industrial municipal solid waste (similar to household municipal solid waste) + sterile medical municipal solid from the amount of municipal solid waste (msw) degraded in the year $T$;

$k_{0}$-degradation rate of the biodegradable municipal solid waste, with $\mathrm{CH}_{4}$ emission, 0.185 [-];

$k_{1}$-degradation rate of the municipal solid waste $(\mathrm{G}+\mathrm{P})$, with $\mathrm{CH}_{4}$ emission, $0.1[-]$

$k_{2}$-degradation rate of the municipal solid waste $(\mathrm{P}+\mathrm{C}+$ tex $)$, with $\mathrm{CH}_{4}$ emission, $0.06[-]$;

$k_{3}$-degradation rate of the municipal solid waste (wood + straw), with $\mathrm{CH}_{4}$ emission, 0.03 [-];

$k_{n}$-degradation rate of the municipal solid waste (sludge or mud), with $\mathrm{CH}_{4}$ emission, 0.185 [-];

$k_{4}$-degradation rate of the municipal solid waste (industrial, similar to household municipal solid waste), with $\mathrm{CH}_{4}$ emission, 0.09 [-];

$$
\mathrm{TDOC}_{\text {disoved }}=\sum(A+B+C+D+E+G)_{T},[\mathrm{Gg}]
$$

where: $A, B, C, D, E, G$ amounts of DOC generated by the types of municipal solid waste (msw) that reached the landfill;

$Q_{\text {mswtekenintoconsid. }}$-amount of municipal solid waste (msw) disposed of in the year $T\left(Q_{\mathrm{msw}, T}\right)+$ amount of municipal solid waste (msw) remained non-degraded in the year $T-1\left(Q_{\text {mswundegrad, } T-1}\right),[\mathrm{Gg}]$.

$\mathrm{DOC}_{\mathrm{f}}$-fraction of the municipal solid waste $(\mathrm{msw})$ that biodegrade in the landfill due to the environmental conditions [\%]. As a rule, it is pre-defined with values [0.5 - 0.77] according to the recommendations of the IPCC for CEECs. The empirical calculation, by using Tabarasan formula, $[0.014 T+0.28]$ where $-T$ is the annual average temperature, in ${ }^{\circ} \mathrm{C}$, for the environmental areas in Romania, yielded the values: $45 \%, 55 \%, 70 \%, 80 \%$. There is a close relation between the outside temperature in the area of the municipal solid waste landfill (msw) and the inside of the municipal solid waste landfill.

1.3333 , that is $(16 / 12)$, is the conversion factor of the carbon in $\mathrm{CH}_{4}$.

$F$-the correction factor of the emission of LFG with $\mathrm{CH}_{4}$ content; it depends on the management of the municipal solid waste $(\mathrm{msw})$ at the landfill; this factor involved the level of compaction of the municipal solid waste (msw) in the landfill and its values are:

1) if the municipal solid waste is not compacted, (0.40);

2) if the municipal solid waste is compacted by using a compactor and a bull- 
dozer (0.6);

3) if the municipal solid waste is compacted with two bulldozers and two compactors $(0.8-0.9)$. To note that there is no value of 1 because there is no perfect management of the municipal solid waste (msw).

$F_{r}$ is a correction factor of the fraction of $\mathrm{CH}_{4}$ in the LFG. According to the recommendations of the IPCC experts, these values are between $40 \%-60 \%$ (Pipatti \& Svardal, 2006).

\section{Case Study}

For this study, we have used information received from the manager of the landfill about the amounts of municipal solid waste (msw) disposed of volumes of LFG with $\mathrm{CH}_{4}$ content collected in 2011 and 2012, as follows:

- 2011-7,500,000 $\mathrm{m}^{3}, 5640[\mathrm{Gg}]$, for the amount of municipal solid waste (msw) (see below);

- 2012-7,470,000 $\mathrm{m}^{3}, 5363[\mathrm{Gg}]$, for the amount of municipal solid waste (msw) (see below);

For 2011 and 2012, the emission of $\mathrm{CH}_{4}$ is calculated as the difference between the amounts of $\mathrm{CH}_{4}$ generated [Gg], calculated and collected.

To calculate that Equation (1) has been used, as follows:

$$
\begin{aligned}
& \mathrm{CH}_{4}(\mathrm{Gg} / \text { year }) \\
& =\left(\mathrm{Q}_{\text {mswdegrad }, T}\right) *\left(\% \mathrm{TDOC}_{\text {disolved }, T}\right) *\left(\mathrm{DOC}_{\mathrm{f}}\right) *(16 / 12) *(F) *\left(F_{r}\right)^{\circledR *},[\mathrm{Gg}](1) \\
& \quad \text { [Vieru, 2017a: pp. 436-454], [Vieru, 2017b: pp. 191-209] }
\end{aligned}
$$

where:

$Q_{\text {mswdegrad, } P}$ is the amount of municipal solid waste (msw) degraded in the reference year $A_{T}$, based on the value - $m$-, according to the methodology previously presented. For the estimation, Equation (3) has been used:

$$
\begin{aligned}
Q_{\mathrm{mswdegrad}, T} & =\left(Q_{\mathrm{msw}, T}+Q_{\mathrm{mswundegrad}, T-1}\right) *[1-\exp (-K t)]^{\circledR *}[\mathrm{Gg}], \\
Q_{\mathrm{mswdegrad}, 2011} & =\left(Q_{\mathrm{msw}, 2011}+Q_{\mathrm{mswundegrad}, 2010}\right) *[1-\exp (-K t)][\mathrm{Gg}]
\end{aligned}
$$

where:

$Q_{\mathrm{msw}, 2011}=361.000 \quad[\mathrm{Gg}]$, amount of municipal solid waste (msw) disposed of in the landfill in 2011;

$Q_{\text {mswundegrad } 2010}=496.989[\mathrm{Gg}]$, amount of municipal solid waste (msw) remained non-degraded, in the landfill in 2010, $(1-\exp (-K t))$ expressed $\left(1-\mathrm{e}^{-K\left(\frac{25-m}{12}\right)}\right), m=7$ ( $m$-value for the year of calculation $A_{T}=11$; it shall fulfill 2 conditions:

1) $7 \leq m \leq 18$,

2) $\sum 0+m_{1}+m_{2}+m_{3}+m_{4}+m_{5}+m_{6}+m_{7}+m_{8}+m_{9}+m_{10}+m_{11} \leq(145-7)$.

The equation: $\sum 0+9+7+14+13+12+11+9+8+7+10+7 \leq 13$, yield 107 $\leq 138$ [Vieru, 2017a: pp. 436-454], [Vieru, 2017b: pp. 191-209].

Consequently: 


$$
Q_{\text {mswdegrad, } 2011}=(361.000+496.989) *\left(1-\mathrm{e}^{-K\left(\frac{25-m}{12}\right)}\right)[\mathrm{Gg}]
$$

For $K=0.4$ and $m=7$, the equation becomes:

$$
\begin{gathered}
Q_{\text {mswdegrad } 2011}=(361.000+496.989) *\left(1-\mathrm{e}^{-K\left(\frac{25-7}{12}\right)}\right)[\mathrm{Gg}], \\
Q_{\text {mswdegrad,2011 }}=387.125[\mathrm{Gg}] \\
Q_{\text {mswundegrad,2011 }}=(361.000+496.989)-387.125 \quad[\mathrm{Gg}] \\
Q_{\text {mswundegrad,2011 }}=470.864 \quad[\mathrm{Gg}]
\end{gathered}
$$

Equation (12) calculated \%TDOC ${\text { dissolved, } T^{*}}$

$$
\% \mathrm{TDOC}_{\mathrm{dissolved}, T}=\left(\mathrm{TDOC}_{\mathrm{dissolved}, T}\right) /\left(Q_{\mathrm{msw} \text { taken in to consid }, T}\right),[\%],{ }^{(\circledR *}
$$

$\mathrm{TDOC}_{\text {dissolved, } T}$ is the Total DOC in the year $T,[\mathrm{Gg}]$.

It has been defined by using Equation (5):

$$
\mathrm{TDOC}_{\text {dissolved } 2011}=\sum[A+B+C+D+E+G][\mathrm{Gg}],{ }^{\circledR *}
$$

$A, B, C, D, E, G$ are calculated for 2011 , by using appropriate equations:

$$
\begin{gathered}
A=Q_{\text {mswdegrad }, T} * \% \mathrm{MSW}_{\text {biodegrad }, T} * k_{0}[\mathrm{Gg}],{ }^{(\circledR)} \\
A_{2011}=Q_{\text {mswdegrad,2011 }} * \% \mathrm{MSW}_{\text {biodegrad,2011 }} * k_{0},[\mathrm{Gg}]
\end{gathered}
$$

$k_{0}=0.185$-Degradation rate down to DOC of the biodegradable municipal solid waste (msw) according to chapter V-Municipal solid waste (recommended by IPCC).

$$
Q_{\text {mswdegrad }, 2011}=387.125 \quad[\mathrm{Gg}] \text {; }
$$

$\% \mathrm{MSW}_{\text {biodegrad }, 2011}=51.2$, percentage pre-defined for 2011 (see Table 1$)$;

$$
\begin{gathered}
A_{2011}=387.125 * 0.512 * 0.185=36.668[\mathrm{Gg}] \\
B=Q_{\mathrm{mswdegrad}, T} * \% \mathrm{MSW}_{(\mathrm{G}+\mathrm{P}) \operatorname{degrad}, T} * k_{1}[\mathrm{Gg}],{ }^{\circledR *} \\
B_{2011}=Q_{\mathrm{mswdegrad}, 2011} * \% \mathrm{MSW}_{(\mathrm{G}+\mathrm{P}) \operatorname{degrad}, 2011} * k_{1},[\mathrm{Gg}]
\end{gathered}
$$

$k_{1}=0.1$-degradation rate down to DOC of the municipal solid waste $(\mathrm{P}+\mathrm{G})$ according to chapter V-Municipal solid waste (recommended by IPCC);

$\% \mathrm{MSW}_{(G+P) \text { degrad,2011 }}=16$, percentage pre-defined for 2011 (see Table 1 );

$$
\begin{gathered}
B_{2011}=387.125 * 0.16 * 0.1=6.194,[\mathrm{Gg}] \\
C=Q_{\mathrm{mswdegrad}, T} * \% \mathrm{MSW}_{(\mathrm{P}+\mathrm{C}+\text { tex. }) \text { degrad }, T} * k_{2}[\mathrm{Gg}]^{\circledR *} \\
C_{2011}=Q_{\mathrm{mswdegrad}, 2011} * \% \mathrm{MSW}_{(\mathrm{P}+\mathrm{C}+\text { text } .) \text { degrad }, 2011} * k_{2}[\mathrm{Gg}]
\end{gathered}
$$

$k_{2}=0.06$-degradation rate down to DOC of the municipal solid waste $(\mathrm{P}+\mathrm{C}$ + tex) according to chapter V-Municipal solid waste (recommended by IPCC); $\% \mathrm{MSW}_{(\mathrm{P}+\mathrm{C}+\text { text. }) \text { degrad,2011 }}=16.8$ percentage predefined for 2011 (see Table 1$)$;

$$
\begin{gathered}
C_{2011}=387.125 * 0.168 * 0.06=3.902[\mathrm{Gg}] \\
D=Q_{\mathrm{mswdegrad}, T} * \% \mathrm{MSW}_{(\text {Wood }+ \text { straw }) \text { degrad }, T} * k_{3},[\mathrm{Gg}]
\end{gathered}
$$




$$
D_{2011}=Q_{\mathrm{mswdegrad}, 2011} * \% \mathrm{MSW}_{(\text {Wood }+ \text { straw }) \text { degrad }, 2011} * k_{3},[\mathrm{Gg}]
$$

$k_{3}=0.03$-degradation rate down to DOC of the municipal solid waste (wood + straw) according to chapter V-Municipal solid waste (recommended by IPCC);

$\% \mathrm{MSW}_{(\text {wood+straw)degrad,2011 }}=3$, percentage predefined for 2011 (see Table 1);

$$
\begin{gathered}
D_{2011}=387.125 * 0.03 * 0.03=0.348,[\mathrm{Gg}] \\
E=Q_{\mathrm{mswdegrad}, T} * \% \mathrm{MSW}_{\text {sludg,degrad }, T} * k_{n},[\mathrm{Gg}] \\
E_{2011}=Q_{\mathrm{mswdegrad}, 2011} * \% \mathrm{MSW}_{\text {sludg,degrad }, 2011} * k_{n},[\mathrm{Gg}]
\end{gathered}
$$

$k_{n}=0.185$-Degradation rate down to DOC of thesludge according to chapter $\mathrm{V}$-Municipal solid waste (recommended by IPCC);

$\% \mathrm{MSW}_{\text {sludg,degrad,2011 }}=1$, percentage predefined for 2011 (see Table 1);

$$
\begin{gathered}
E_{2011}=387.125 * 0.01 * 0.185=0.716,[\mathrm{Gg}] \\
G=Q_{\mathrm{mswdegrad}, T} * \% \mathrm{MSW}_{\text {ind,degrad }, T} * k_{4},[\mathrm{Gg}]^{\circledR} * \\
G_{2011}=Q_{\text {mswdegrad,2011 }} * \% \mathrm{MSW}_{\text {ind,degrad,2011 }} * k_{4},[\mathrm{Gg}]
\end{gathered}
$$

$k_{4}=0.09$-Degradation rate down to DOC of the industrial municipal solid waste (msw) according to chapter V-Municipal solid waste (recommended by IPCC);

$\% \mathrm{MSW}_{\text {ind,degrad,2011 }}=12$, percentage predefined for 2011(see Table 1);

$$
G_{2011}=387.125 * 0.12 * 0.09=4.181,[\mathrm{Gg}]
$$$$
\mathrm{TDOC}_{\text {dissolved,2011 }}=36.668+6.194+3.902+0.348+0.716+4.181=52.01,[\mathrm{Gg}]
$$

$$
\% \mathrm{TDOC}_{\mathrm{dissolved}, T}=\left(\mathrm{TDOC}_{\mathrm{dissolved}, T}\right) /\left(Q_{\mathrm{msw} \text { taken in to consid }, T}\right),[\%]^{\circledR *}
$$$$
\% \mathrm{TDOC}_{\text {dissolved,2011 }}=\left(\mathrm{TDOC}_{\text {dissolved,2011 }}\right) /\left(Q_{\mathrm{msw} \text { taken in to consid,2011 }}\right) \quad[\%]
$$$$
Q_{\text {msw taken in to consid }, T}=Q_{\mathrm{msw}, T}+Q_{\mathrm{msw} \text { undegrad }, T-1},[\mathrm{Gg}]^{\circledR{ }^{\circledR} *}
$$$$
Q_{\text {msw taken in to consid,2011 }}=Q_{\text {msw }, 2011}+Q_{\text {mswundegrad } 2010},[\mathrm{Gg}]
$$$$
Q_{\text {msw taken in to consid, } 2011}=361.000+496.989=857.989,[\mathrm{Gg}]
$$

$\% \mathrm{TDOC}_{2011}=52.01 / 857.989=0.06062$; that is $6.062 \%$.

The amount of $\mathrm{CH}_{4}$ generated for 2011 is calculated with Equation (1), as follows:

$\left(\mathrm{CH}_{4}\right)_{\text {generated } / 2011}=387.125 * 0.06062 * 1.3333 * 0.5 * 0.8 * 0.5=6.25785,[\mathrm{Gg}]$

where:

- $\quad 385.125[\mathrm{Gg}]$ is the amount of municipal solid waste (msw) degraded in 2011 that generated DOC and further on $\mathrm{CH}_{4}$;

- 6.062 is \%TDOC in the landfill;

- 0.5 is the $\mathrm{DOC}_{\mathrm{f}}$ implicit value that takes into account the environmental conditions of the location of the municipal solid waste landfill;

- $1.3333(16 / 12)$ is $\mathrm{C}$ in $\mathrm{CH}_{4}$;

- 0.8 is the management of the municipal solid waste landfill in the reference year; 
- 0.5 is the content \% $\mathrm{CH}_{4}$ in the LFG, [\%].

To note that the $\mathrm{CH}_{4}$ emission increasing gradually, not suddenly, according to the environmental conditions at the location of the landfill. A certain amount of municipal solid waste will remain non-degraded and will be taken into account for the next year, so that the degradation of the municipal solid waste (msw) will generate, again, DOC and $\mathrm{CH}_{4}$.

In 2011, the economic operator collected 5640 [Gg] $\mathrm{CH}_{4}$, which was used for green energy production.

At the same time, the operatore mitted the difference in the atmosphere:

$$
\left(\mathrm{CH}_{4}\right)_{\text {generated,2011 }}-\left(\mathrm{CH}_{4}\right)_{\text {collected,2011 }}=6.25785-5.640=0.61785 \quad[\mathrm{Gg}]
$$

The equivalent $\mathrm{CO}_{2}$ is:

$$
\left(\mathrm{CO}_{2}\right)_{\text {equivalent, } 2011}=\left(\mathrm{CH}_{4}\right)_{\text {emitted, } 2011} * 21=0.61785 * 21=12.97485,[\mathrm{Gg}]
$$

In 2012, for the same municipal solid waste landfill located in Chitila-RudeniIridex, the amount of municipal solid waste ( $\mathrm{msw}$ ) disposed of was:

$Q_{\mathrm{msw}, 2012}=371.568,[\mathrm{Gg}]$ municipal solid waste (msw) disposed of at the landfill.

$Q_{\text {mswundegrad,2011 }}=470.864 \quad[\mathrm{Gg}]$ amount of municipal solid waste (msw) remained non-degraded since 2011;

$$
\begin{gathered}
Q_{\mathrm{msw} \text { taken in to consid }, T}=Q_{\mathrm{msw}, T}+Q_{\text {mswundegrad }, T-1},[\mathrm{Gg}] \\
Q_{\text {mswtaken in to consid,2012 }}=371.568+470.864=842.432 \quad[\mathrm{Gg}]
\end{gathered}
$$

To calculate the amount of municipal solid waste (msw) degraded in 2012, we used Equation (3):

$$
Q_{\mathrm{mswdegrad}, T}=\left(Q_{\mathrm{msw}, T}+Q_{\mathrm{mswundegrad}, T-1}\right) *[1-\exp (-K t)][\mathrm{Gg}]
$$

$K=0.4$ and $m=9$, according to the NOMOGRAMA of the landfill, (see Figure 7).

$$
Q_{\text {mswdegrad }, 2012}=350.452 \quad[\mathrm{Gg}] \text {, }
$$

For the amount of municipal solid waste (msw) remained non-degraded at the end of 2012, we used Equation (4):

$$
\begin{gathered}
Q_{\text {mswundegrad }, 2012}=\left(Q_{\mathrm{msw}, 2012}+Q_{\text {mswundegrad }, 2011}\right)-Q_{\text {degrad }, 2012} \\
Q_{\text {mswundegrad }, 2012}=(371.568+470.864)-350.452=491.980 \quad[\mathrm{Gg}]
\end{gathered}
$$

By using Equation (12), we calculated \%TDOC ${\text { dissolved, } T^{*}}$

$$
\% \mathrm{TDOC}_{\text {dissolved }, T}=\left(\mathrm{TDOC}_{\text {dissolved }, T}\right) /\left(Q_{\text {msw taken in to consid }, T}\right) \quad[\%]
$$

TDOC $_{\text {dissolved,T }}$ Total DOC(Organic Dissolved Carbon), was established by using Equation (5):

$$
\mathrm{TDOC}_{\text {dissolved }, 2012}=\sum[A+B+C+D+E+G][\mathrm{Gg}]
$$

$A, B, C, D, E, G$ are calculated for 2012 , by using appropriate equations: 


$$
A_{2012}=Q_{\text {mswdegrad,2012 }} * \% \mathrm{MSW}_{\text {biodegrad }, 2012} * k_{0},[\mathrm{Gg}]
$$

$k_{0}=0.185$ degradation rate down to DOC of the biodegradable municipal solid waste, according to chapter V-Municipal solid waste (recommended by IPCC);

$$
Q_{\text {mswdegrad,2012 }}=350.452 \quad[\mathrm{Gg}]
$$

$\% Q_{\text {mswbidegrad } 2012}=58$, percentage predefined for 2012 (see Table 1 );

$$
\begin{gathered}
A_{2012}=350.452 * 0.58 * 0.185=37.603[\mathrm{Gg}] \\
B=Q_{\mathrm{mswdegrad}, T} * \% \mathrm{MSW}_{(\mathrm{G}+\mathrm{P}) \text { degrad }, T} * k_{1},[\mathrm{Gg}] \\
B_{2012}=Q_{\mathrm{mswdegrad}, 2012} * \% \mathrm{MSW}_{(G+\mathrm{P}) \text { degrad }, 2012} * k_{1},[\mathrm{Gg}]
\end{gathered}
$$

$k_{1}=0.1$-Degradation rate down to DOC of the municipal solid waste $(\mathrm{P}+\mathrm{G})$ according to chapter V-Municipal solid waste (recommended by IPCC);

$\% \mathrm{MSW}_{(\mathrm{G}+\mathrm{P}) \mathrm{degrad}, 2012}=13.8$, percentage predefined for $2012($ see Table 1$)$;

$$
B_{2012}=350.452 * 0.138 * 0.1=4.836,[\mathrm{Gg}]
$$

$$
C=Q_{\mathrm{mswdegrad}, T} * \% \mathrm{MSW}_{(\mathrm{P}+\mathrm{C}+\text { text. }) \text { degrad }, T} * k_{2},[\mathrm{Gg}]
$$

$$
C_{2012}=Q_{\mathrm{mswdegrad}, 2012} * \% \mathrm{MSW}_{(\mathrm{P}+\mathrm{C}+\text { text. }) \text { degrad }, 2012} * k_{2},[\mathrm{Gg}]
$$

$k_{2}=0.06$-Degradation rate down to DOC of the municipal solid waste $(\mathrm{P}+\mathrm{C}$ + tex) according to chapter V-Municipal solid waste (recommended by IPCC); $\% \mathrm{MSW}_{(\mathrm{P}+\mathrm{C}+\text { text.)degrad }, 2012}=10.7$, percentage predefined for 2012 (see Table 1);

$$
\begin{gathered}
C_{2012}=350.452 * 0.107 * 0.06=2.249,[\mathrm{Gg}] \\
D=Q_{\mathrm{mswdegrad}, T} * \% \mathrm{MSW}_{(\text {wood+straw)degrad }, T} * k_{3},[\mathrm{Gg}] \\
D_{2012}=Q_{\text {mswdegrad }, 2012} * \% \mathrm{MSW}_{(\text {(wood+straw)degrad,2012 }} * k_{3},[\mathrm{Gg}]
\end{gathered}
$$

$k_{3}=0.03$-Degradation rate down to DOC of the municipal solid waste (wood + straw) according to chapter V-Municipal solid waste (recommended by IPCC);

$\% \mathrm{MSW}_{(\text {wood }+ \text { straw }) 2012}=3$, percentage predefined for 2012 (see Table 1$)$;

$$
\begin{gathered}
D_{2012}=350.452 * 0.03 * 0.03=0.315[\mathrm{Gg}] \\
E=Q_{\mathrm{mswdegrad}, T} * \% \mathrm{MSW}_{\text {sludg,degrad }, T} * k_{n},[\mathrm{Gg}] \\
E_{2012}=Q_{\text {mswdegrad }, 2012} * \% \mathrm{MSW}_{\text {sludg,degrad,2012 }} * k_{n},[\mathrm{Gg}]
\end{gathered}
$$

$k_{n}=0.185$-degradation rate down to DOC of the sludge according to chapter $\mathrm{V}$-Municipal solid waste (recommended by IPCC);

$\% \mathrm{MSW}_{\text {sludg,degrad,2012 }}=1.5$, percentage predefined for 2012 (see Table 1$)$;

$$
\begin{gathered}
E_{2012}=350.452 * 0.015 * 0.185=0.973,[\mathrm{Gg}] \\
G=Q_{\mathrm{mswdegrad}, T} * \% \mathrm{MSW}_{\text {ind,degrad }, T} * k_{4},[\mathrm{Gg}] \\
G_{2012}=Q_{\mathrm{mswdegrad}, 2012} * \% \mathrm{MSW}_{\text {ind,degrad,2012 }} * k_{4},[\mathrm{Gg}]
\end{gathered}
$$

$k_{4}=0.09$, degradation rate down to DOC of the industrial municipal solid waste + sterile medical municipal solid waste according to chapter V-Municipal solid waste (recommended by IPCC);

$\% \mathrm{MSW}_{\text {ind,degrad,2012 }}=13$, percentage predefined for 2012 (see Table 1); 


$$
\begin{gathered}
G_{2012}=350.452 * 0.13 * 0.09=4.100,[\mathrm{Gg}] \\
\mathrm{TDOC}_{\text {dissolved } 2012}=37.603+4.836+2.249+0.315+0.973+4.100=50.077 \quad[\mathrm{Gg}] \\
\% \mathrm{TDOC}_{\text {dissolved }, T}=\left(\mathrm{TDOC}_{\text {dissolved }, T}\right) /\left(Q_{\mathrm{msw} \text { taken in to consid }, T}\right) \quad[\%] \\
\% \mathrm{TDOC}_{\text {dissolved }, 2012}=\left(\mathrm{TDOC}_{\text {dissolved }, 2012}\right) /\left(Q_{\mathrm{msw} \text { taken in to consid, } 2012}\right) \quad[\%] \\
Q_{\mathrm{msw} \text { taken in to consid, }, T}=Q_{\mathrm{msw}, T}+Q_{\text {mswundegrad }, T-1}, \quad[\mathrm{Gg}] \\
Q_{\mathrm{msw} \text { taken in to consid, } 2012}=Q_{\mathrm{msw}, 2012}+Q_{\mathrm{mswundegrad}, 2011},[\mathrm{Gg}] \\
Q_{\mathrm{msw} \text { taken in to consid, } 2012}=371.568+470.864=842.432 \quad[\mathrm{Gg}] \\
\% \mathrm{TDOC}_{2012}=50.077 / 842.432=0.05944 ; \text { that is } 5.944 \% .
\end{gathered}
$$

The amount of $\mathrm{CH}_{4}$ generated in 2012 is calculated by applying Equation (1), as follows:

$$
\left(\mathrm{CH}_{4}\right)_{\text {generated } / 2012}=350.452 * 0.05944 * 1.3333 * 0.5 * 0.9 * 0.5=6.24945[\mathrm{Gg}]
$$

where:

- $350,452[\mathrm{Gg}]$ is the amount of municipal solid waste (msw) degraded in 2012 that generated $\mathrm{DOC}$ and $\mathrm{CH}_{4}$;

- 5.944 is \%TDOC in the landfill;

- 0.5 is the $\mathrm{DOC}_{\mathrm{f}}$ implicit value that takes into account the environmental conditions of the location of the municipal solid waste landfill;

- $1.3333(16 / 12)$ is the $\mathrm{C}$ in $\mathrm{CH}_{4}$;

- 0.9 is the management of the municipal solid waste landfill in the year of calculation;

- 0.5 is the content $\% \mathrm{CH}_{4}$ in the LFG, [\%].

To note that the $\mathrm{CH}_{4}$ emission increasing gradually, not suddenly, according to the environmental conditions of the location of the municipal solid waste landfill. A certain amount of municipal solid waste (msw) from the municipal solid waste landfill will remain non-degraded and shall be taken into account for the next year, so that the degradation process of the municipal solid waste (msw) will generate again DOC and $\mathrm{CH}_{4}$.

For 2012, the economic operator collected $5363[\mathrm{Gg}] \mathrm{CH}_{4}$, amount used for green energy production.

At the same time, the operator emitted the difference in the atmosphere:

$$
\left(\mathrm{CH}_{4}\right)_{\text {generated,2012 }}-\left(\mathrm{CH}_{4}\right)_{\text {collected, 2012 }}=6.24945-5.363=1.1315 \text { [Gg] }
$$

The equivalent $\mathrm{CO}_{2}$ is:

$$
\left(\mathrm{CO}_{2}\right)_{\text {equivalent,2012 }}=\left(\mathrm{CH}_{4}\right)_{\text {emitted,2012 }} * 21=1.1315 * 21=23.7615[\mathrm{Gg}]
$$

For the municipal solid waste landfill located in Chitila-Rudeni-Iridex, data (amounts of municipal solid waste (msw) disposed of/volume of $\mathrm{CH}_{4}$ collected) has been received for 2013, 2014, 2015, 2016. The graph of the evolution of the greenhouse effect in Chitila-Rudeni-Iridex landfill for 2000-2016 is presented in Figure 9. 


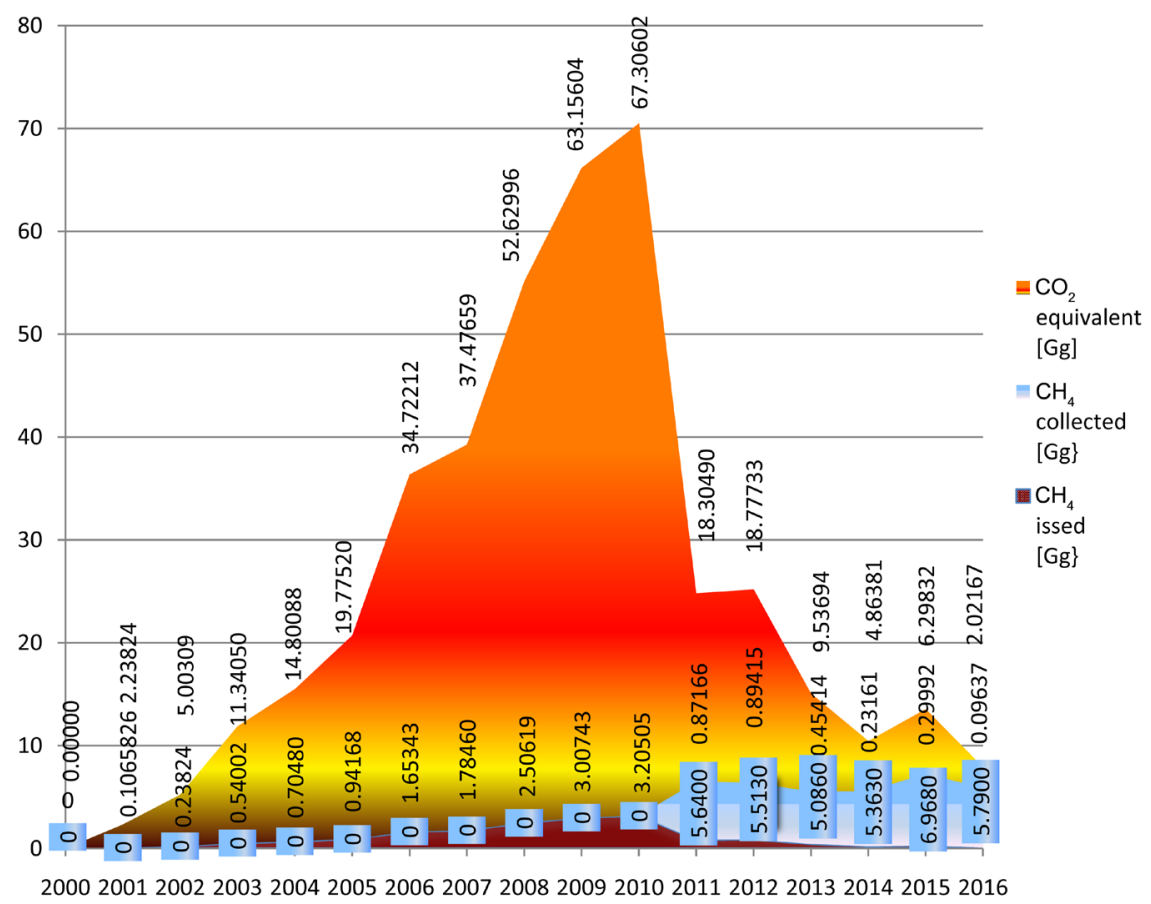

Figure 9. Graph of the evolution of the greenhouse effect in Chitila-Rudeni-Iridex municipal solid waste landfill between 2000-2016.

Starting with 2011, the greenhouse effect significantly decreased.

\section{Conclusion}

The estimation formula used to calculate the emission of $\mathrm{CH}_{4}$ in the municipal solid waste landfills proposed by us is reproducible, credible and coherent. Due to its working methodology, it does not affect the achievements of other researchers interested in the estimation of the $\mathrm{CH}_{4}$ emissions in municipal solid waste landfills, as it uses:

- The variation of the air pressure;

- The calculation of stoichiometric coefficients of the many reactions that take place in the municipal solid waste landfill;

- It establishes the LFG flow with CH4 content and the calculation of the LFG flow;

- It collects information about: environmental temperature and precipitations at the location of the landfill, the variation of the air pressure, the orientation and the speed of the wind, the thickness of the cover of the landfill, the permeability of the coverage material of the landfill and others;

- It determines the pressure of the LFG in the municipal solid wasteland fill, it correlates it with the air pressure and it calculates then the $\mathrm{CH}_{4}$ flow.

All the findings of the researchers, all empirical and advanced calculation formulas can be used by the government or by the owner of the municipal solid wasteland fill.

Eventually, the decision to calculate by using a certain technology or a certain 
algorithm will be taken based on the costs involved, the duration and the accuracy of the results.

The formula proposed by us to calculate the estimation of the $\mathrm{CH}_{4}$ emission does not imply the collection of lots of information [amount of municipal solid waste (msw), $[\mathrm{Gg}]$, disposed of per year, and the percentages of types of municipal solid waste (msw): rapidly biodegradable, moderately biodegradable, slowly biodegradable in the landfill], the environmental conditions at the location (wet periods of time with precipitations, dry periods without precipitations, alternation of freezing/de-freezing periods expressed by a number of months $-m$-), number of bulldozers and compactors that work at the landfill, all that is information of interest. The environmental conditions expressed by the number of months $m$ lead to the biodegradation of the municipal solid waste with $\mathrm{CH}_{4}$ emissions.

We believe that NOMOGRAMA ${ }^{\circledR}$, typical of all municipal solid wasteland fills because it includes the year when the disposal of the municipal solid waste (msw) started, is extremely interesting because it allows calculation of the amount de municipal solid waste (msw) degraded in the reference year that, through the amount of DOC, allows the estimation of the $\mathrm{CH}_{4}$ generated. More attention shall be given to the quality of the silty leachate that can be introduced in the landfill, if the air intrusion is properly controlled.

The working algorithm ${ }^{\circledR}$ allows removal from the calculation of the types of municipal solid waste (msw) that are not biodegradable but reach the municipal solid wasteland fill.

The realities of the $21^{\text {st }}$ century reveal the need to manage the LFG in an ecological-rational manner in order to achieve the diminution of the greenhouse effect generated by the management of the municipal solid waste (msw). Definitely, the LFG with $\mathrm{CH}_{4}$ content has an economic value that can be enhanced through proper treatment and brought to the quality of the natural $\mathrm{CH}_{4}$.

\section{Clarification}

For clarifications regarding the working methodology and the approach of the New Method of calculating the emission of the LFG with $\mathrm{CH} 4$ content, the works from the bibliography, numbered [Vieru, 2017a: pp. 436-454] and [Vieru, 2017b: pp. 191-209], will be consulted. In the 2 articles, there is enough data leading to the clarification of possible ambiguities. For any other assumptions or positions I state: all models for calculating the emission of the LFG with $\mathrm{CH}_{4}$ content from landfills (msw) presented by other researchers are valid. When implementing a model, the realization costs will make a difference. I also state that Danila Vieru's method of calculating the emission of LFG with $\mathrm{CH}_{4}$ content does not lead to high costs. It requires only specifications regarding the percentage composition of the waste (msw) arrived in the landfill (msw); important: the amount of waste (msw) disposed of at the considered landfill (expressed in SI (international system of units)) is also a necessity, the percentage estimation of 
the types of waste arrived in the landfill. Any ambiguities or questions, raised when reading this document, can be resolved, in writing, to the email address danila.vieru@gmail.com, the author of the proposed working method.

\section{Conflicts of Interest}

The author declares no conflicts of interest regarding the publication of this paper.

\section{References}

Atabi, F. et al. (2014). Calculation of $\mathrm{CH}_{4}$ and $\mathrm{CO}_{2}$ Emission Rate in Kahrizak Landfill Site with LandGEM Mathematical Model. World Sustainability Forum 2014-Conference Proceedings Paper. http://www.sciforum.net/conference/wsf-4

Barlaz, M. A. et al. (2012). Controls on Landfill Gas Collection Efficiency: Instantaneous and Life Time Performance. http://www.tandfonline.com/loi/uawm20

Bellenoue, D. et al. (2007). Biogaz issu de la mise endécharge: Comment optimiser son captage? ADEME Éditions, Angers.

Bentley, H. W. et al. (2002). Baro-Pneumatic Estimation of Landfill Gas Generation Rates at? Four Landfills in the Southeastern United States.

http://www.hgcinc.com/Bentleyetalpaper.pdf

Conestoga-Rovers \& Associates (2010). British Columbia Ministry of Environment, Landfill Gas Management Facilities Design Guidelines.

Fei, X. C. et al. (2015). Quantification of Parameters Influencing Methane Generation Due to Biodegradation of Municipal Solid Waste in Landfills and Laboratory Experiments. Waste Management, 55, 276-287. www.elsevier.com/locate/wasman https://doi.org/10.1016/j.wasman.2015.10.015

Godlove, C. et al. (2018). IPCC Guideline Vol. 5 (Waste). Greenhouse Gas Inventory System Training Workshop, 10-13 September 2018, Bangkok, Thailand. https://sustainabledevelopment.un.org/content/unosd/documents/4479[08]IPPC.Vol.5. WASTE.Godlove.pdf

Guidance on the Management of Landfill Gas (2004). www.environment-agency.gov.uk

Hosseini, S. S. et al. (2018). Estimation of Landfill Gas Generation in a Municipal Solid Waste Disposal Site by LandGEM Mathematical Model. Global Journal of Environmental Science and Management, 4, 493-506.

International Best Practices Guide for LFGE Projects (2012). Chapter 6 Landfill Gas Modeling.

https://www.globalmethane.org/documents/toolsres_lfg_IBPGAppendixA.pdf

Isin, E. O. (2013). Determination of Landfill Gas by Using Mathematical Models. https://acikerisim.deu.edu.tr/xmlui/

Jacobs, J. et al. (2001). Comparison of Methane Emission Models and Methane Emission Measurements, NV Afvalzorg.

https://www.afvalzorg.nl/content/uploads/2018/03/Comparison-of-Methane-emissionmodels-to-Methane-emission-measurements.pdf

Ludwig, V. et al. (2010). User's Manual Colombia Landfill Gas Model Version 1.0. https://www.globalmethane.org/documents/models/pdfs/UsersManualColombiaLFGM odelEnglish.pdf

Meres, M. (2005). Analyse de la composition du biogazenvue de l'optimisation de sa production et de son exploitation dans des centres de stockage des déchetsménagers. 
Mihoc, G. et al. (1980). micăenciclopediematematică, Edituratehnică. Bucharest, p. 93.

Oonk, H. (2001). Literature Review: Methane from Landfills Methods to Quantify Generation, Oxidation and Emission, Sustainable Landfill Foundation. afvalzorg.nl.

Peer, R. L. et al. (1992). Development of an Empirical Model of Methane from Landfills. https://scholar.google.ro/scholar?q=Peer,+R.+L.+et+al.+(1992).+Development+of+an+ Empiri-

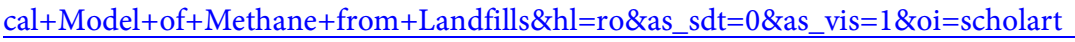

Pipatti, R., \& Svardal, P. (2006). IPCC Guidelines for National Greenhouse Gas Inventories. https://www.rti.org/publication/solid-waste-disposal

Prud'homme, E. (2001). Gérerer le gaz de décharge; Techniques et recomandations. Copyright ADEME Editions, Angers.

Romania's Climate Wikipedia (2008). https://en.wikipedia.org/wiki/Climate_of_Romania

Romania's Population by Locality on January 1, 2016. www.insse.ro/cms/ro/content/populațiaRomâniei-pe-localitati-la-1-ianuarie-2016

Scharff, H. et al. (2017). Methods to Ascertain Methane Emission of Landfills. https://www.afvalzorg.nl/content/uploads/2017/09/Paper-methods-to-ascertain-metha ne-emission.pdf

Scharff, H., Jacobs, J. et al. (2006). Applying Guidance for Methane Emission Estimation for Landfills. Waste Management, 26, 417-429 https://doi.org/10.1016/j.wasman.2005.11.015 https://scholar.google.ro/scholar?q=Applying+guidance+for+methane+emission+esti

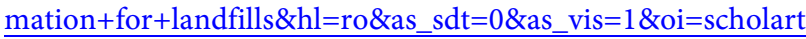

Vieru, D. (2017a). Nomograma of a Landfill (msw) - Setting Parameter Values. Atmospheric and Climate Science, 7, 436-454. http://www.scirp.org/journal/acs https://doi.org/10.4236/acs.2017.74032

Vieru, D. (2017b) A New Approach Method of $\mathrm{CH}_{4}$ Emission Estimation from Landfills Municipal Solid Waste (MSW). Atmospheric and Climate Science, 7, 191-209. https://doi.org/10.4236/acs.2017.72014

Voicu, G. (2016). Ingineriadepozităriiecologice a deșeurilor. Bucharest: POLITEHNICA Press.

Voicu, G., \& Vieru, D. et al. (2019). Mathematical Models Which Predict $\mathrm{CH}_{4}$ Emissions from MSW Landfills-Comparations, Annals of Faculty Engineering Hunedoara- International Journal of Engineering Tome XVII.

Word Press.com (2014). Disposal of Solid Wastes and Residual Matter. https://3ch1213npc.files.wordpress.com/2014/01/5-landfills_part-i.pdf 